\title{
Effect of antioxidant-rich propolis and bee pollen extracts against D-glucose induced type 2 diabetes in rats
}

\author{
Hassan Laaroussi ${ }^{\text {a }}$, Meryem Bakour ${ }^{a}$, Driss Ousaaid ${ }^{\mathrm{a}}$, Abderrazak Aboulghazi ${ }^{\mathrm{a}}$, \\ Pedro Ferreira-Santos ${ }^{\mathrm{b}}$, Zlatina Genisheva ${ }^{\mathrm{b}}$, José Antonio Teixeira ${ }^{\mathrm{b}}$, Badiaa Lyoussi ${ }^{\mathrm{a}}{ }^{\text {** }}$

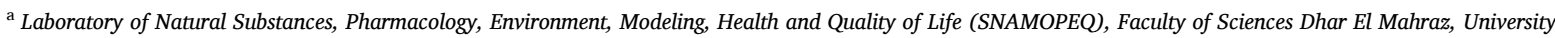 \\ Sidi Mohamed Ben Abdellah, Fez, Morocco \\ ${ }^{\mathrm{b}}$ CEB - Centre of Biological Engineering, University of Minho, Campus de Gualtar, 4710-057 Braga, Portugal
}

\section{A R T I C L E I N F O}

\section{Keywords:}

Propolis

Bee pollen

Type 2 diabetes

D-glucose

Dyslipidemia

Hepato-renal damage

\begin{abstract}
A B S T R A C T
The present study was designed to investigate the preventive effect of propolis, bee pollen and their combination on Type 2 diabetes induced by D-glucose in rats. The study was carried out by feeding daily two concentrations (100 and $200 \mathrm{mg} / \mathrm{Kg} \mathrm{BW)} \mathrm{of} \mathrm{propolis} \mathrm{or} \mathrm{bee} \mathrm{pollen} \mathrm{(or} \mathrm{their} \mathrm{combination} \mathrm{to} \mathrm{normal} \mathrm{(non-diabetic)} \mathrm{and} \mathrm{diabetic}$ rats for a period of 16 weeks. In vivo biochemical changes associated to diabetes are induced by drinking a solution containing $10 \%$ of D-glucose (diabetic rats). The in vitro antioxidant activity was also evaluated and the chemical composition of propolis and bee pollen extracts was determined by UHPLC-DAD. Phytochemical composition of propolis and bee pollen revealed the presence of several natural antioxidants, such as hydroxycinnamic acids, hydroxybenzoic acids, flavonoids, flavan-3-ols and stilbens. The major antioxidant compound present in propolis was Naringin $(290.19 \pm 0.2 \mathrm{mg} / \mathrm{Kg})$ and in bee pollen was apigenin $(162.85 \pm 17.7 \mathrm{mg} / \mathrm{Kg})$. These results have been related with a high antioxidant activity, more intense in propolis extract. In rats, the administration of D-glucose had induced hyperglycemia $(13.2 \pm 0.82 \mathrm{mmol} / \mathrm{L})$, increased plasmatic insulin levels $(25.10 \pm 2.12 \mathrm{U} / \mathrm{L})$ and HOMA-IR index (14.72 \pm 0.85$)$ accompanied with dyslipidemia, elevation of hepatic enzyme levels, and a change in both serum renal biomarkers and plasmatic calcium. The coadministration of propolis and bee pollen extracts alone or in combination restored these biochemical parameters and attenuated the deleterious effects of D-glucose on liver and kidney functions. Furthermore, these effects were better attenuated in the combined therapy-prevented diabetic rats. Hence, it is possible to conclude that propolis and bee pollen can be used as a preventive natural product against diabetes induced dyslipidemia and hepato-renal damage.
\end{abstract}

\section{Introduction}

Type 2 diabetes (T2D) or non-insulin-dependent diabetes mellitus (NIDDM) is a chronic progressive disease characterized by chronic fasting hyperglycemia and resulting in defective insulin action (Association, 2013). This pathology is most often linked to life style changes, obesity, physical inactivity and family antecedents. Currently, its incidence is increasing exponentially, and affects more than 350 million people worldwide, estimates are that it will grow to about 642 million people by 2040 (Ogurtsova et al., 2017). Several hypotheses were put in place in order to explain the mechanisms involved in the manifestation of diabetes and its associated risks. The most solid one is that linking to oxidative stress, in fact hyperglycemia is a main factor triggering oxidative stress via the overproduction of reactive oxygen species (ROS) (Fakhruddin, Alanazi, \& Jackson, 2017). In turn, the excess of ROS generated by hyperglycemia interact with the free and sulphydryl amine groups of the intracellular and extracellular proteins and subsequently forming the amadori products, which then will decompose and form the glycation products (AGEs) (Al-Malki, 2013). The chronic elevation of plasma glucose level has deleterious effects on the secretion of insulin from beta cells. Its action on peripheral tissues, blood vessels, nerve cells and other cell types is known as gluco-toxicity (Poitout et al., 2010). T2D can be associated with many complications affecting multiple organs such as eyes, kidneys, heart and brain (Sina, Graffy, \& Simmons, 2018).

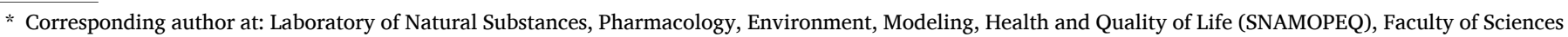
Dhar El Mahraz, University Sidi Mohamed Ben Abdellah, 30000 Fez, Morocco.

E-mail address: lyoussi@gmail.com (B. Lyoussi).
} 
Diabetes mellitus (DM) induces diabetic nephropathy and diabetic hepatotoxicity through different mechanisms including, the activation of nuclear factor kappa B (NF- $\mathrm{kB}$ ) and mitogen-activated protein kinase (MAPKs) signaling pathways as well as the down-regulation of nuclear factor erythroid 2-related factor 2 (Nrf2) and heme oxygenase-1 (HO-1) expression (Ebrahimi et al., 2019; Karim, Rahman, Changlek, \& Tangpong, 2020). Undeniably, these complications could not just be due to the oxidative stress induced by diabetes but also due to the attenuation of the physiological defense system via glycosylation of the antioxidant enzymes. The relationship between diabetes, hepato-renal damage and oxidative stress has been the subject of previous studies (El Menyiy et al., 2019; Ogar, Egbung, Nna, Atangwho, \& Itam, 2019).

Nature is an inexhaustible source of products and bioactive molecules that can be used as alternative treatments, being propolis one of them. Propolis, known as a miracle drug, is a sticky, resinous substance made by a complex mixture of bee-released and plant-derived compounds. In general, raw propolis is composed of around 50\% resin, 30\% waxes, $10 \%$ essential oils, $5 \%$ pollen and $5 \%$ of various organic compounds (Al-Hariri, 2011). Phytochemical analyzes of propolis have revealed the presence of several bioactive molecules. Among these molecules we quote quercetin, phenolic acids and its esters, caffeic acid phenyl ester (CAPE) (Hoşnuter et al., 2004) steroids, terpenoids and amino acids (Burdock, 1998). Also, propolis has a very large fraction of minerals and trace elements including zinc ( $\mathrm{Zn}$ ) which intervenes as cofactors of antioxidant enzymes (Pietta, Gardana, \& Pietta, 2002). Numerous studies have shown that propolis has different therapeutic properties such as antioxidant, antibacterial, antiviral, antifungal, anticancer, antiangiogenic and hepatoprotective (Sforcin \& Bankova, 2011). Furthermore, in vitro studies have shown that propolis inhibits $\alpha$-amylase and $\alpha$-glucosidase activities as part of its anti-hyperglycemic mechanism (El-Guendouz et al., 2016).

Pollen is another bee product that is extremely rich in bioactive molecules, like flavonoids. Numerous biological effects are attributed to bee pollen, which include antioxidant (Leja, Mareczek, Wyżgolik, Klepacz-Baniak, \& Czekońska, 2007), cardioprotective, hepatoprotective, and anti-inflammatory effects (Rzepecka-Stojko et al., 2015).

Until now, no study had examined the combined effect of propolis and bee pollen on type 2 diabetes and its related metabolic disorders. Therefore, the aim of this study was to determine the chemical composition of antioxidant polyphenols in propolis and bee pollen extracts and also to evaluate the influence of several doses of these extracts and their mixture in the prevention of $\mathrm{T} 2 \mathrm{D}$, dyslipidemia and hepatorenal dysfunction induced by D-glucose in rats.

\section{Materials and methods}

\subsection{Propolis and bee pollen samples and extract preparation}

Propolis and fresh bee pollen samples were harvested, on May 2018, from hives installed in Skoura (Middle Atlas, Morocco) where the predominant vegetation consists of Pinus, sylvestris, Ceratonia siliqua, Rosmarinus officinalis, Juniperus oxycedrus, Thymus vulgaris, Bupleurum spinosum, Globularia alypum and Cistus landanferus. The extracts were prepared by macerating $1 \mathrm{~g}$ of each sample in $30 \mathrm{~mL}$ of ethanolic aqueous solution $(70 \% \mathrm{v} / \mathrm{v})$ with mechanical stirring for one week at room temperature. The final extract was filtered, centrifuged at $3000 \times$ $\mathrm{g}$ for $10 \mathrm{~min}$ and the supernatant was collected for further analysis. Subsequently, the filtrate was concentrated in a rotary evaporator. Distillated water was added to obtain two concentrations (100 and 200 $\mathrm{mg} / \mathrm{kg} \mathrm{BW}$ ) for animals'feeding (Park \& Ikegaki, 1998).

\subsection{Chemical analysis of extracts}

\subsubsection{Total phenolics content (TPC)}

The quantification of phenolics content was determined following the method of Folin-Ciocalteau described by (Miguel, Doughmi, Aazza, Antunes, \& Lyoussi, 2014). $500 \mu \mathrm{L}$ of Folin-Ciocalteau (0.2 N) reagent and $400 \mu \mathrm{L}$ of sodium carbonate solution (7.5\%) were added to $100 \mu \mathrm{L}$ ethanolic extract of propolis or bee pollen. The intensity of produced color was measured at $760 \mathrm{~nm}$ (Perkin Elmer Lambda $40 \mathrm{UV} / \mathrm{VIS}$ spectrophotometer,) after incubating the mixture in the dark for $2 \mathrm{~h}$. Gallic acid $(0.071$ to $0.719 \mathrm{mg} / \mathrm{mL})$ was used as a standard to achieve the calibration curve $\left(R^{2}=0.999\right)$ and the result was expressed in milligram gallic acid equivalent (GAE) per gram of sample (mg GAE/g).

\subsubsection{Total flavonoids content (TFC)}

Total flavonoids were determined according to the procedure described by (Kong, Mat-Junit, Aminudin, Ismail, \& Abdul-Aziz, 2012). Briefly, one hundred microliters of bee pollen or propolis ethanolic extracts was mixed with sodium nitrite (5\%) and $150 \mu \mathrm{L}$ of $\mathrm{AlCl}_{3}(10 \%)$. After $5 \mathrm{~min}, 200 \mu \mathrm{L}$ of $\mathrm{NaOH}(1 \%)$ was added and placed in the dark for $1 \mathrm{~h}$. The intensity of the produced color was measured at $510 \mathrm{~nm}$. Quercetin $(0.261-1.423 \mathrm{mg} / \mathrm{mL})$ was used as a standard to achieve the calibration curve $\left(\mathrm{R}^{2}=0.997\right)$ and the flavonoids content was expressed in milligram of the quercetin equivalent $(\mathrm{QE})$ per gram of sample (mg $\mathrm{QE} / \mathrm{g}$ ).

\subsubsection{Identification and quantification of polyphenols compounds by $U P L C-D A D$}

Samples were analyzed by Shimatzu N expera X2 UPLC chromatograph equipped with Diode Array Detector (DAD) (Shimadzu, SPDM20A) according to the method described by (Ferreira-Santos et al., 2019). Separation was performed on a reversed phase Aquity UPLC BEH C18 column $(2.1 \mathrm{~mm} \times 100 \mathrm{~mm}, 1.7 \mu \mathrm{m}$ particle size; from Waters $)$ and a precolumn of the same material at $40{ }^{\circ} \mathrm{C}$. The flow rate was $0.4 \mathrm{~mL} /$ min. HPLC grade solvents water/formic acid $0.1 \%$ (A) and acetonitrile (B) were used. The elution gradient for solvent $B$ was as follows: from 0.0 to 5.5 min eluent $B$ at $5 \%$, from 5.5 to 17 min linearly increasing from 5 to $60 \%$, from 17.0 to $18.5 \mathrm{~min}$ a linearly increasing from 60 to $100 \%$; the column was equilibrated at $5 \%$ from 18.5 to $30.0 \mathrm{~min}$. Phenolic compounds were identified by comparing their UV spectra and retention times with that of corresponding standards. All standards used were of analytical grade (purity level above 94\%) and procured from Sigma Aldrich (St. Louis, USA). Quantification was carried out using calibration curves for each compound analyzed using concentrations between 250 and $2.5 \mathrm{mg} / \mathrm{mL}$. In all cases, the coefficient of linear correlation was $\mathrm{R}^{2}$ greater than 0.99. Compounds were quantified and identified at different wavelengths $(250-370 \mathrm{~nm})$. All analyses were made in triplicate.

\subsection{Evaluation of in vitro antioxidant activity}

\subsubsection{Total antioxidant activity (TAA)}

Total antioxidant activity of propolis or bee pollen samples was evaluated by the phosphomolybdenum method according to the method described by (Prieto, Pineda, \& Aguilar, 1999). $1 \mathrm{~mL}$ of reagent solution (6 $\mathrm{M}$ sulfuric acid, $28 \mathrm{mM}$ sodium phosphate and $4 \mathrm{mM}$ ammonium molybdate) was added to $25 \mu \mathrm{L}$ of ethanolic extract of propolis or bee pollen and the mixture was incubated for $90 \mathrm{~min}$ in a water bath at $95{ }^{\circ} \mathrm{C}$. After, the absorbance was read at $695 \mathrm{~nm}$ and ascorbic acid was used as the standard calibration (0.171 to $0.872 \mathrm{mg} / \mathrm{mL}, \mathrm{R}^{2}=0.999$ ). The results were expressed in milligram of ascorbic acid equivalent (AAE) per gram of sample (mg AAE/g).

\subsubsection{Free radical scavenging activity}

Free radical scavenging activity (DPPH assay) was measured according to the method described by (Miguel et al., 2014). Briefly, $875 \mu \mathrm{L}$ of 2,2-diphenyl-1-picryl-hydrazyl-hydrate (DPPH) solution $(63.4 \mu \mathrm{M}$, prepared in ethanol) was mixed with $25 \mu \mathrm{L}$ of ethanolic extract of propolis or bee pollen, and the mixture reaction was incubated during one hour in the dark. The control consisted in using the solvent of 
extraction instead of the sample. The absorbance was read at $517 \mathrm{~nm}$ and the antiradical activity (\% inhibition) was estimated using the Eq. (1). DPPH inhibition concentration at $50 \%\left(\mathrm{IC}_{50}\right)$ is determined using five different dilutions of each sample, considering that the percent inhibition had to be between $20 \%$ and $80 \%$.

$\%$ inhibition $=\frac{\text { Abscontrol }- \text { Abssample }}{\text { Abscontrol }} \times 100$

\subsection{Experimental animal's protocol}

Sixty six male wistar rats, 11 week old with $173 \pm 3 \mathrm{~g}$ of body weight (BW), were used in this experiment. The animals were housed in a standard environmental condition $\left(23 \pm 3{ }^{\circ} \mathrm{C}\right.$ with $12 \mathrm{~h}$ light/dark cycles) and fed with standard rodent chow and water ad libitum. Ethical approval was obtained from Sidi Mohamed Ben Abdellah University, Fez, under the responsibility of the Animal Facility and the Laboratory of Natural Substances, Pharmacology, Environment, Modeling, Health and Quality of Life, University of Sidi Mohamed Ben Abdellah, Fez, Morocco (USMBA-SNAMOPEQ 2017-03). The care and handling of the animals were in accordance with the internationally accepted standard guidelines for the use of animals.

Rats were randomly allocated into 11 groups of six rats.

Groups 1 to 5 are considered normal non-diabetic control groups, whereas groups 6 to 11 are considered diabetic groups (induced by $10 \%$ D-glucose in drinking water throughout the study).

Group 1: received daily by gavage distilled water $(10 \mathrm{~mL} / \mathrm{Kg} \mathrm{BW})$ and had free access to tap water;

Group 2: received daily by gavage propolis extract (200 mg/Kg BW) and had free access to tap water;

Group 3: received daily by gavage bee pollen extract $(200 \mathrm{mg} / \mathrm{Kg}$ BW) and had free access to tap water;

Group 4: received daily by gavage propolis extract (100 mg/Kg BW) and had free access to tap water;

Group 5: received daily by gavage bee pollen extract $(100 \mathrm{mg} / \mathrm{Kg}$ BW) and had free access to tap water;

Group 6: had free access to a drinking solution containing $10 \%$ of Dglucose and received daily by gavage distilled water $(10 \mathrm{~mL} / \mathrm{Kg} \mathrm{BW})$;

Group 7: had free access to a drinking solution containing $10 \%$ of Dglucose and received daily by gavage propolis extract ( $200 \mathrm{mg} / \mathrm{Kg} \mathrm{BW}$ );

Group 8: had free access to a drinking solution containing $10 \%$ of Dglucose and received daily by gavage pollen extract (200 mg/Kg BW);

Group 9: had free access to a drinking solution containing $10 \%$ of Dglucose and received daily by gavage propolis extract ( $100 \mathrm{mg} / \mathrm{Kg} \mathrm{BW})$;

Group 10: had free access to a drinking solution containing $10 \%$ of Dglucose and received daily by gavage bee pollen extract $(100 \mathrm{mg} / \mathrm{Kg}$ BW);

Group11: had free access to a drinking solution containing $10 \%$ of Dglucose and received daily by gavage $100 \mathrm{mg} / \mathrm{Kg} \mathrm{BW}$ of propolis extract $+100 \mathrm{mg} / \mathrm{Kg} \mathrm{BW}$ of bee pollen extract.

The study lasted for 16 weeks. At the end of study, fasted rats were anaesthetized with light diethyl ether. Blood sample was withdrawn from each rat by retro-orbital puncture, collected into tubes, and then plasma was separated by centrifugation $(2000 \times \mathrm{g})$ during $10 \mathrm{~min}$.

The treatment duration was chosen based on the results of (Katsuda et al., 2014; Ousaaid et al., 2020). The pollen and propolis extracts doses were selected according to (El Menyiy, Al Waili, Bakour, Al-Waili, \& Lyoussi, 2016; El Ghouizi, El Menyiy, Falcão, Vilas-Boas, \& Lyoussi, 2020).

\subsubsection{Biochemical analysis}

Plasmatic levels of aspartate aminotransferases (AST), alanine aminotransferases (ALT), lactate dehydrogenase (LDH), alkaline phosphatase (ALP), triglycerides (TG), total cholesterol (TC), low-density lipoprotein (LDL-C), very-low-density lipoprotein (VLDL), high density lipoprotein (HDL-C), uric acid, creatinine, urea, albumin, total protein, blood glucose, plasma insulin levels were determined by radioimmunoassay method (Rat insulin RIA kit, Millipore, St Charles, MO, USA). Plasma, sodium $\left(\mathrm{Na}^{+}\right)$, potassium $\left(\mathrm{K}^{+}\right)$were analyzed using ion-selective potentiometry method (Architect c8000i biochemistry analyzer), and plasma calcium $\left(\mathrm{Ca}^{2+}\right)$ was determined basing on it reaction with Arsenazo III (2,2'-[1,8-Dihydroxy-3,6-disulphonaphthylene-2,7-bisazo]bisbenzenear-sonic acid). The intensity of produced color was measured bichromatically at $660 / 700 \mathrm{~nm}$ (Architect c8000i biochemistry analyzer).. Model homeostasis evaluation (HOMA-IR) (Eq. (2)), and homeostatic model- $\beta$ (HOMA- $\beta$ ) (Eq. (3)) were calculated following formula described by (Matthews et al., 1985), quantitative insulin sensitivity check index (QUICKI) (Eq. (4)) was determined according to (Katz et al., 2000).

$$
\begin{aligned}
& \text { HOMA }-I R=\frac{\operatorname{Insulin}\left(\frac{U}{L}\right) \times \operatorname{Glucose}\left(\frac{m m o l}{L}\right)}{22.5} \\
& \text { HOMA }-\beta=\frac{20 \times \operatorname{Insulin}\left(\frac{\mathrm{U}}{\mathrm{L}}\right)}{\operatorname{Glucose}\left(\frac{\mathrm{mmol}}{\mathrm{L}}\right)}-3.5
\end{aligned}
$$

QUICKI $=\frac{1}{\left(\text { logfastinginsulinlevel }\left(\frac{\mu \mathrm{U}}{\mathrm{ml}}\right)+\operatorname{logfastingbloodglucose}\left(\frac{\mathrm{mg}}{\mathrm{dl}}\right)\right)}$

\subsubsection{Body weight change and organ weights}

The BW in each group of rats was measured at the beginning and at the end of the experiment using an electronic balance. Percentage changes were calculated by comparing the diabetic control group (Group 6) with normal non-diabetic group (Group 1) and the diabetic treated groups with diabetic control. Liver, pancreas and kidney were removed at the end of the study and weighted.

\subsection{Statistical analysis}

All data are presented as mean $\pm \mathrm{SD}$ (standard deviation). Statistical comparisons between the groups were performed with one-way analysis of variance (ANOVA) followed by Tukey test using GraphPad Prism ${ }^{\circledR}$ software (version 5.0; GraphPad software, Inc., San Diego, USA). Significance was accepted at $\mathrm{p}<0.05$.

\section{Results}

\subsection{Phytochemical analysis and in vitro antioxidant activity of extracts}

As presented in Fig. 1, the chemical analysis shows that propolis contains $89.71 \pm 5.12 \mathrm{mg} \mathrm{GAE} / \mathrm{g}$ of total phenolic contents, total flavonoid content is $38.56 \pm 2.47 \mathrm{mgQE} / \mathrm{g}$ ) and total antioxidant capacity is $96.17 \pm 7.38 \mathrm{mg} \mathrm{AAE} / \mathrm{g}$. The phenolic and flavonoid contents in bee pollen sample are lower $(19.68 \pm 0.12 \mathrm{mg} \mathrm{GAE} / \mathrm{g}$ and $7.35 \pm 0.16$ $\mathrm{mgQE} / \mathrm{g}$, respectively); and the total antioxidant capacity is $26.46 \pm$ $0.59 \mathrm{mgAAE} / \mathrm{g}$. Regarding free radical scavenging activity, DPPH test was evaluated and it showed the following results of $\mathrm{IC}_{50}: 0.17 \pm 0.00$ $\mathrm{mg} / \mathrm{mL}$ for propolis and $0.91 \pm 0.02 \mathrm{mg} / \mathrm{mL}$ for bee pollen.

\subsection{Polyphenols compounds identification}

Fourteen polyphenolic compounds were quantified in the propolis sample and thirteen were quantified in bee pollen (Table 1). As shown in Table 1, the major components detected in propolis were naringin $(290.19 \pm 0.2 \mathrm{mg} / \mathrm{kg})$, hesperidin $(271.77 \pm 0.0 \mathrm{mg} / \mathrm{kg})$ and rosmarinic acid $(222.02 \pm 6.2 \mathrm{mg} / \mathrm{kg})$. However, apigenin $(162.85 \pm 17.7 \mathrm{mg} / \mathrm{kg})$, rosmarinic acid $(127.30 \pm 6.2 \mathrm{mg} / \mathrm{kg})$ and naringin $(113.71 \pm 6.8 \mathrm{mg} /$ 

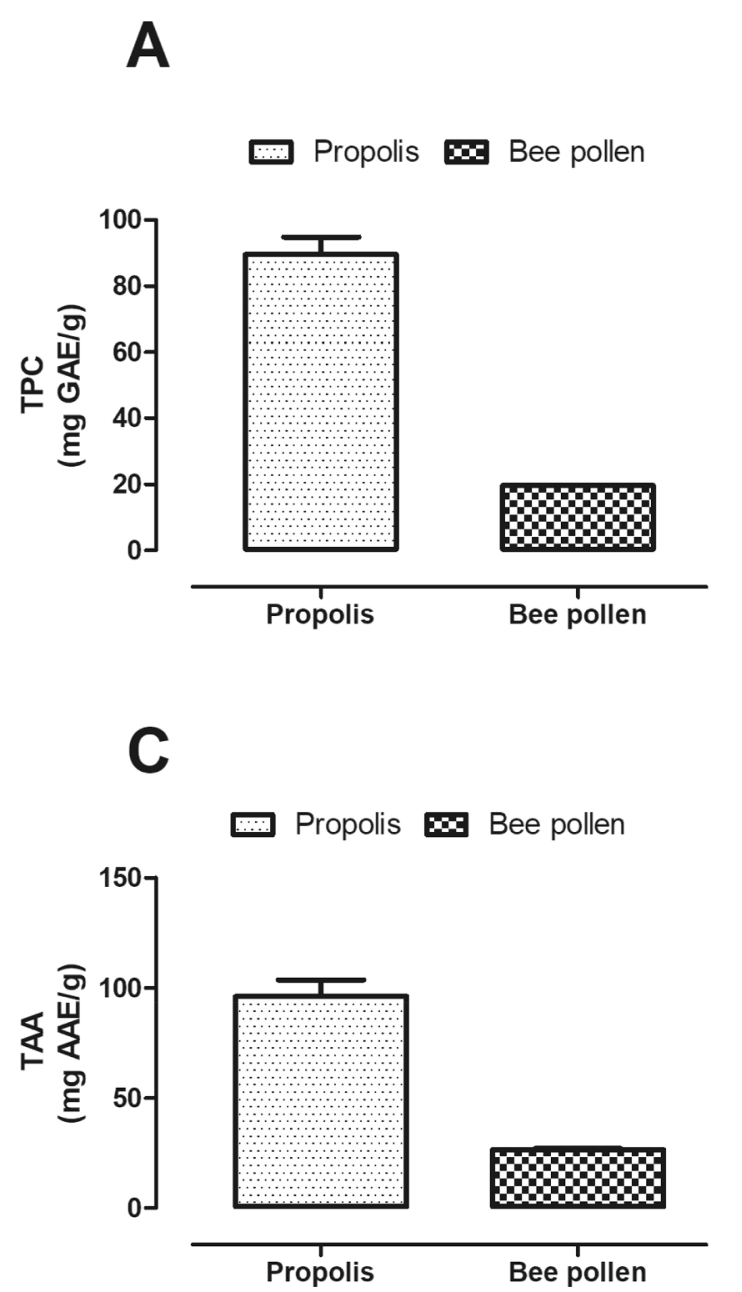

B

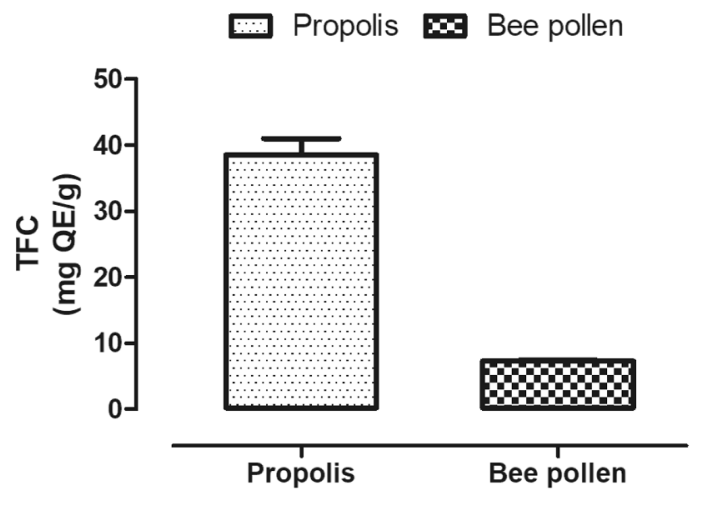

D

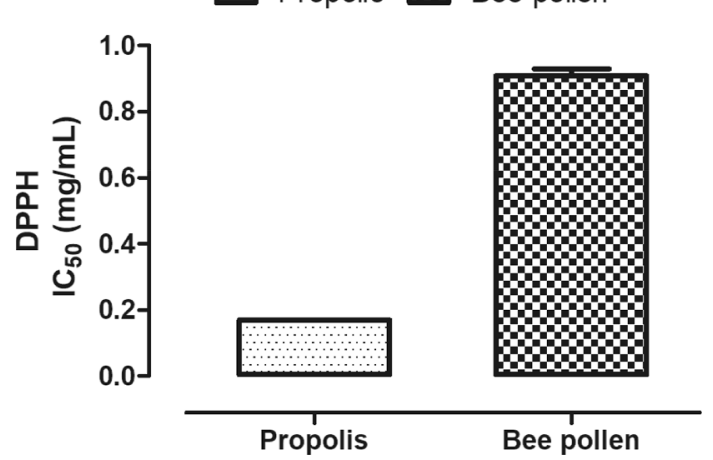

Fig. 1. A: Total phenolic content (TPC), B: flavonoids (TFC), C: Total antioxidant activity (TAA), and D: radical scavenging activity (DPPH) of propolis and fresh bee pollen extracts.

Table 1

Polyphenols compounds identification and quantification of propolis and fresh bee pollen samples using UPLC-DAD.

\begin{tabular}{lll}
\hline Compounds $(\mathrm{mg} / \mathrm{kg})$ & Propolis & Bee pollen \\
\hline Hydroxycinnamic acids & & \\
Ferrulic acid & $40.60 \pm 0.6$ & $17.17 \pm 0.4$ \\
Cinnamic acid & n.d. & $46.01 \pm 7.8$ \\
$o$-Coumaric acid & $35.47 \pm 0.2$ & $27.10 \pm 1.9$ \\
Chlorogenic acid & $25.31 \pm 0.0$ & n.d. \\
Rosmarinic acid & $222.02 \pm 6.2$ & $127.30 \pm 6.2$ \\
Hydroxybenzoic acids & & \\
Gallic acid & n.d. & $32.54 \pm 2.2$ \\
Vanilic acid & $10.58 \pm 0.1$ & $6.13 \pm 0.1$ \\
Ellagic acid & $37.94 \pm 0.1$ & $13.02 \pm 0.0$ \\
Flavan-3-ols & & \\
Catechin & $18.83 \pm 0.1$ & n.d. \\
Flavonoids & & $113.71 \pm 6.8$ \\
Naringin & $290.19 \pm 0.2$ & $15.63 \pm 6.8$ \\
Hesperidin & $271.77 \pm 0.0$ & $48.12 \pm 2.8$ \\
Quercetin & $14.78 \pm 0.2$ & $162.85 \pm 17.7$ \\
Apigenin & $50.37 \pm 0.8$ & n.d. \\
Kaempferol & $26.48 \pm 1.2$ & $95.36 \pm 3.7$ \\
Rutin & $34.37 \pm 1.3$ & $44.00 \pm 0.4$ \\
Stilbens & & $748.9 \pm 56.8$ \\
Resveratrol & $86.25 \pm 0.2$ & \\
Total & $1165.0 \pm 6.3$ & \\
\hline
\end{tabular}

Values of polyphenols compounds are expressed in concentration $(\mathrm{mg} / \mathrm{kg})$ mean \pm SD of 3 experiments. n.d: not detected. $\mathrm{kg}$ ) were the most predominant polyphenolic compounds quantified in analyzed bee pollen. Other detected polyphenolic compounds are quercetin, gallic acid, kaempferol, chlorogenic acid, rutin, resveratrol, cinnamic acid, ellagic acid, ferrulic acid, $o$-coumaric acid, vanilic acid, catechin. However, cinnamic acid and gallic acid were not detected in propolis; kaempferol, chlorogenic acid and catechin were not detected in bee pollen.

\subsection{In vivo effects of propolis and bee pollen extracts \\ 3.3.1. Blood glucose and insulin resistance}

The administration of propolis and bee pollen extracts to nondiabetic animals has no effects in glycemia, insulinemia and associated parameters (Fig. 2). The data presented in (Fig. 2 A) shows a significant increase $(\mathrm{p}<0.001)$ in the fasting blood glucose levels of diabetic rats compared to the control groups. However, the administration of propolis alone at a dose of 100 or $200 \mathrm{mg} / \mathrm{kg}$ BW and bee pollen at the same doses doesn't affect the blood glucose level in nondiabetic control groups. While the co-treatment with propolis at the same doses induce a detectable decrease $(\mathrm{p}<0.01)$ in the fasting blood glucose concentrations compared to control diabetic rats (Group 6). Also the co-administration of bee pollen at two tested doses (100 and 200 $\mathrm{mg} / \mathrm{Kg} \mathrm{BW}$ ) has significantly reduced the fasting blood glucose levels in comparison with non-treated diabetic rats (Group 6). Similarly, the coadministration of the mixture of propolis and bee pollen (Group 11) showed a strong decrease in the blood glucose levels compared to the control diabetic rats and the other treated diabetic groups. 

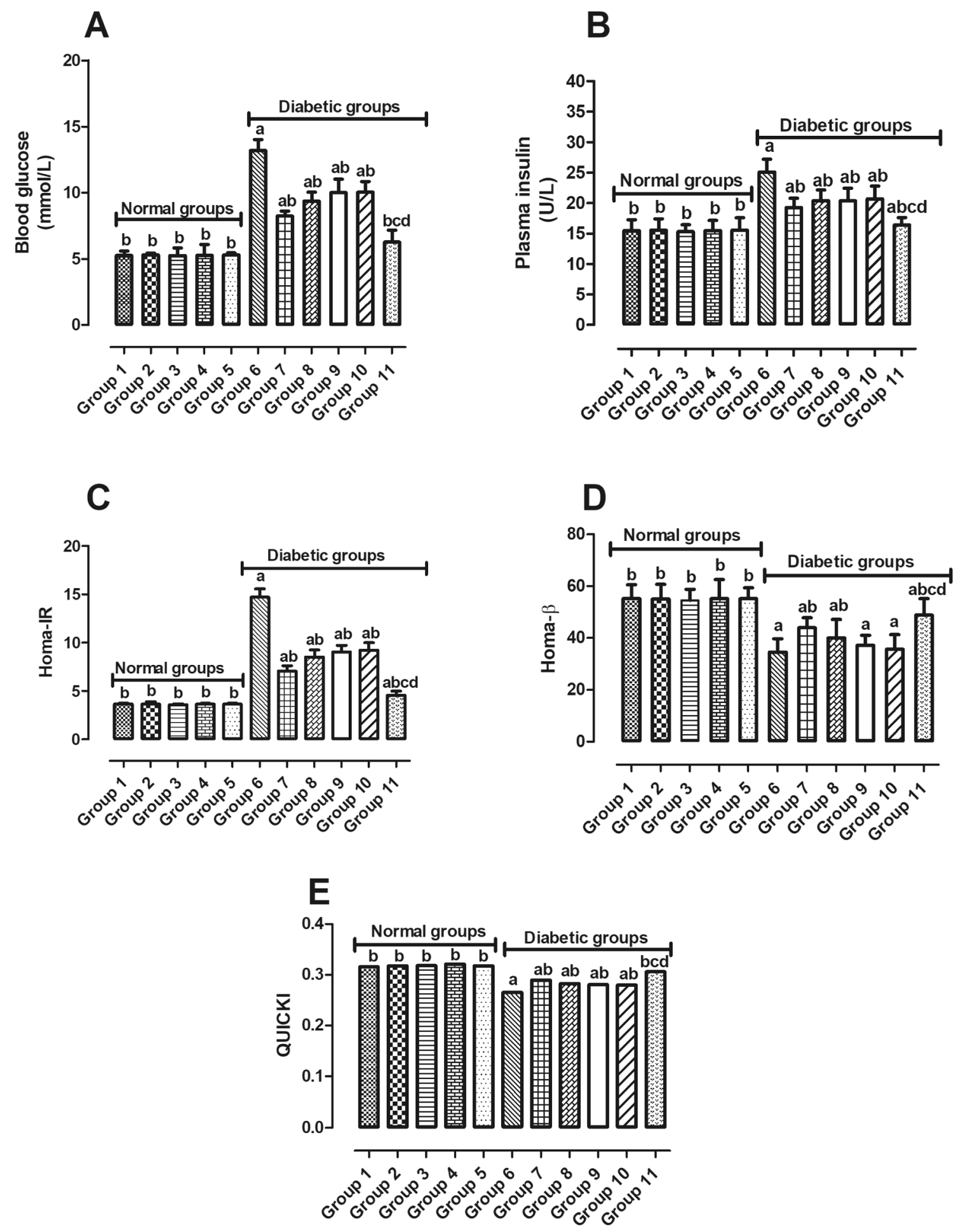

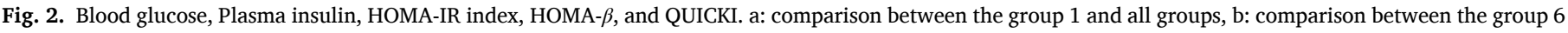
and all groups, c: comparison between group 7 and group 11, d: comparison between group 8 and group 11(the significance started at p $<0.05$ ).

After 16 weeks of D-glucose intake, the plasmatic insulin levels increased significantly (Fig. 2 B). This increase was majorly prevented after oral co-administration of propolis (200 and $100 \mathrm{mg} / \mathrm{kg} \mathrm{BW}$ ) and bee pollen (200 and $100 \mathrm{mg} / \mathrm{kg} \mathrm{BW}$ ). The combined treatment of propolis and pollen (Group 11) showed a greater reduction of plasma insulin levels compared with animals treated with only one type of extract.

Furthermore, the insulin resistance index estimated by HOMA-IR significantly increased $(\mathrm{p}<0.001)$ in rats treated with D-glucose compared to the control non-diabetic group (Group 1). However, the treatment with propolis or bee pollen at two tested doses showed a significant reduction in HOMA-IR index and thus, insulin resistance in comparison with the non-diabetic control group. Moreover, the effect promoted by the extracts is dose dependent and the combined treatment with propolis and bee pollen reduce HOMA-IR $(\mathrm{p}<0.001)$. In addition, the diabetic group (Group 6) expressed a very low value of HOMA- $\beta$. The co-administration of propolis, bee pollen or both showed a significant improvement of all these parameters, with the best data observed in the 
rats which received the combined treatment of propolis and pollen extracts (Group11).

\subsubsection{Plasma lipid profile}

Fig. 3 shows the plasmatic levels of total cholesterol, triglycerides, HDL-cholesterol, LDL-cholesterol and VLDL-cholesterol. The diabetic group (Group 6) showed a significant increase in TC, TG, LDL-C and VLDL ( $p<0.001)$ and decrease in HDL-C $(\mathrm{p}<0.001)$ as compared to the non-diabetic groups (Groups 1 to 5). Treatment with propolis or pollen in non-diabetic rats has no effects in lipid profile, expressed similar values to the rats that received distilled water. The co-treatment with propolis or bee pollen at two tested doses, reversed these increases of TC, TG, LDL-C and VLDL promoted by D-glucose intake and leads to increase in HDL-C $(\mathrm{p}<0.001)$. The results also indicate that the combined cotreatment of extracts (propolis + bee pollen) decreased plasmatic TC, TG, LDL-C and VLDL levels ( $\mathrm{p}<0.001$ ) and increased HDL-C level ( $\mathrm{p}<$ 0.001 ) as compared to the non-treated diabetic group (Group 6) or treated diabetic group with a single extract.

\subsubsection{Plasmatic determinations of renal biomarkers}

Fig. 4 represents the plasmatic levels of creatinine, urea, uric acid and total protein in the control and diabetic groups. The groups that receive $10 \% \mathrm{D}$-glucose (diabetic groups) depict a significant increase in the creatinine, urea, and uric acid levels $(\mathrm{p}<0.001)$, and significant decrease in total protein and albumin levels $(\mathrm{p}<0.001)$, compared to non-diabetic rats. The diabetic group treated with propolis or bee pollen (100 and $200 \mathrm{mg} / \mathrm{kg} \mathrm{BW}$ ) showed a significant reduction of serum creatinine, urea, uric acid and increase in total protein and albumin levels. The diabetic group (Group 11) treated simultaneously with propolis and bee pollen, showed a significant decrease in creatinine, urea, and uric acid ( $\mathrm{p}<0.001$ ), and a significant increase in total protein and albumin compared to non-treated diabetic group (Group 6).

Regarding plasma electrolytes, the data presented in Fig. 4 (F, G,H,I) showed that D-glucose treatment did not cause any significant changes in the serum level of sodium $\left(\mathrm{Na}^{+}\right)$, potassium $\left(\mathrm{K}^{+}\right)$and chloride $\left(\mathrm{Cl}^{-}\right)$. Whereas, it induced a significant decrease in plasma calcium $\left(\mathrm{Ca}^{2+}\right)$ compared with the control group 6 ( $\mathrm{p}<0.05$ ), however, the cotreatment with propolis, bee pollen or both of them has prevented the plasma calcium loss.

\subsubsection{Liver function}

The data in Fig. 5 indicates that diabetic animals expressed a significant increase in ALT, AST, ALP and LDH compared to the control non-diabetic group (Group 1). Daily administration of propolis and bee pollen extracts did not show effects in the control animals, obtaining similar values to those of Group 1. The diabetic group co-treated with propolis or bee pollen at high $(200 \mathrm{mg} / \mathrm{kg} \mathrm{BW})$ or a low $(100 \mathrm{mg} / \mathrm{kg} \mathrm{BW})$ dose, alone or in combination showed a significant improvement in all biomarker levels in comparison with diabetic non-treated group (Group 6).

\subsubsection{Body and organs' weights}

The rats' weights were measured at the beginning and at the end of the experiment. The derived data in table 2 increased significantly ( $\mathrm{p}<$ 0.01 ) the final body weight and body weight gain in the diabetic rats compared to normal rats, the recorded percentage of changes were $40.56 \%$ and $198.18 \%$ respectively. The administration of propolis at a high dose showed a significant decrease in the final body weight and body weight gain compared to the control group, with a percentage change of $-5.72 \%$ and $-36.32 \%$, respectively. The co-treatment with propolis at a low (Group 9) and a high (Group 7) doses showed a significant decrease in the final body weight and body weight gain in comparison with the diabetic group, and the recorded percentage changes were $-15.68 \%$ and $-39.90 \%,-16.78 \%$ and $-44.58 \%$ respectively. The administration of fresh bee pollen at a high dose recorded a final body weight and weight gain in comparison with the control group, the recorded percentage changes were $31.89 \%$ and $140.44 \%$ respectively. The co-administration of propolis at a high and a low doses showed a significant decrease in the final body weight and body weight gain as compared to diabetic group, while the combined co-treatment showed a percentage change in final body weight and weight gain in comparison with the diabetic group $-13.53 \%$ and $-25.28 \%$ respectively.

The body weight change was accompanied by the alteration of the liver, kidneys and pancreas weights. Table 3 showed that the treatment with propolis and bee pollen or both did not affect the organs' relative weight. D-glucose chronic administration decreased significantly the relative weight of kidneys, pancreas and liver. However, the cotreatment with propolis, bee pollen and their combination improved significantly the organs' relative weight, with the best recovery related to the co-treatment with the bee pollen $(200 \mathrm{mg} / \mathrm{kg} \mathrm{BW})$.

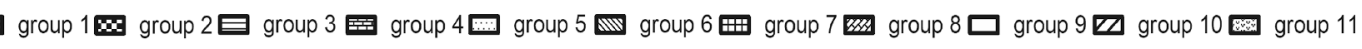

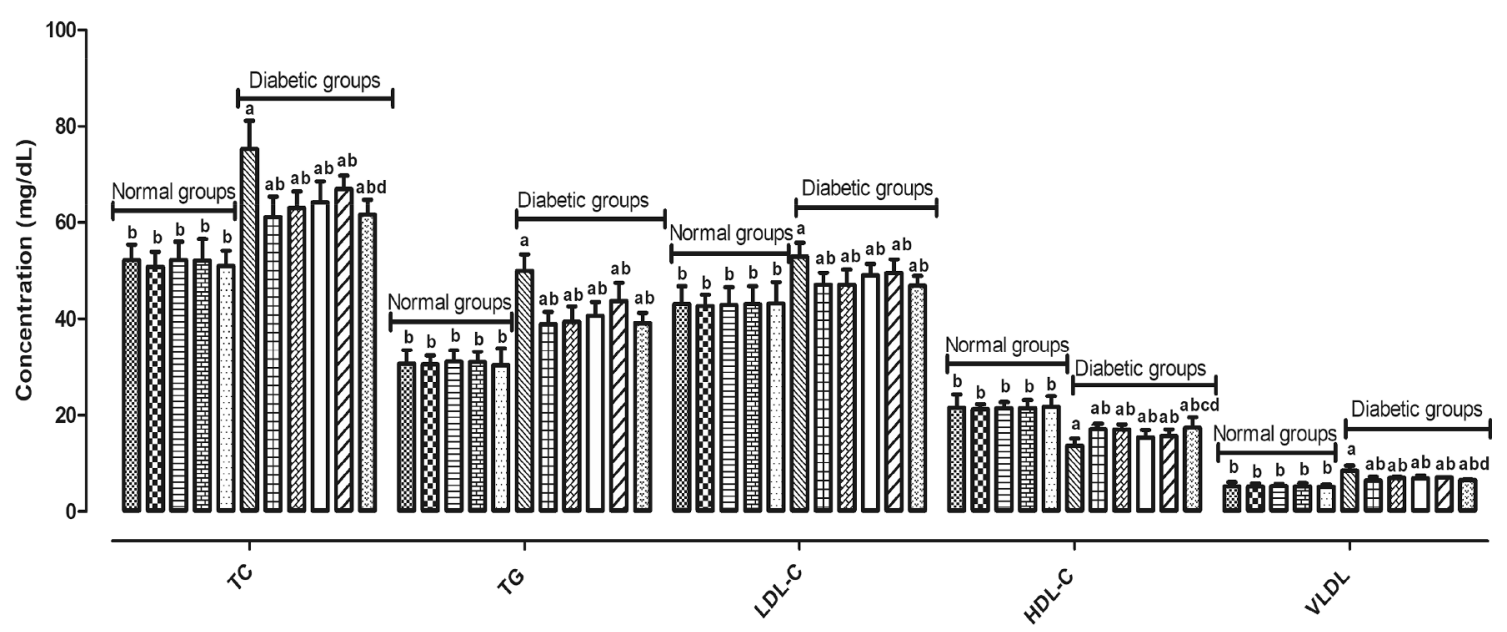

Fig. 3. TC, TG, LDL-C, HDL-C and VLDL levels. a: comparison between the group 1 and all groups, b: comparison between the group 6 and all groups, c: comparison between group 7 and group 11, d: comparison between group 8 and group 11 (the significance started at $\mathrm{p}<0.05$ ). 

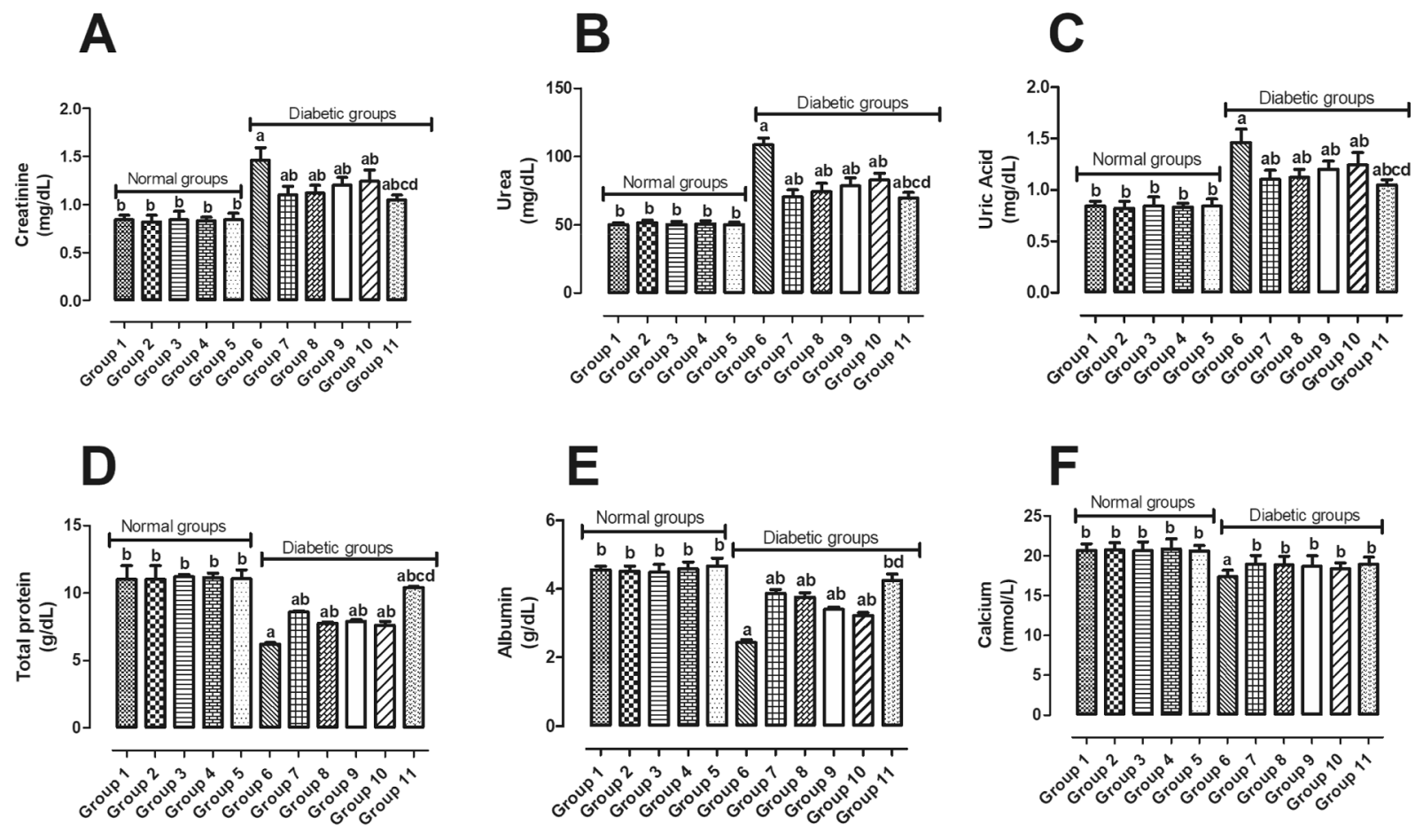

\section{G}
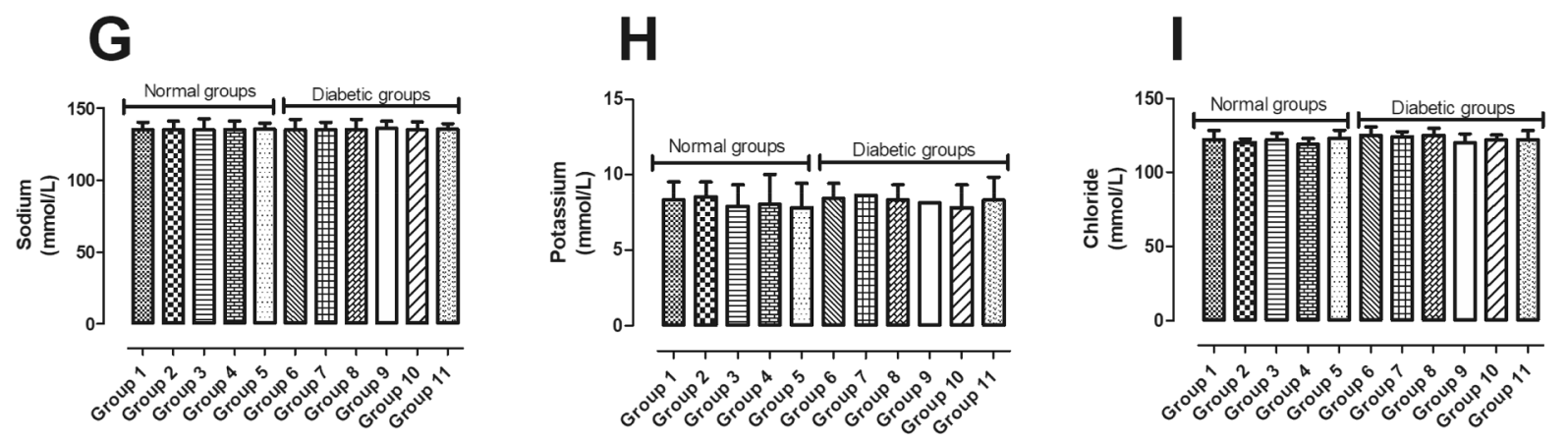

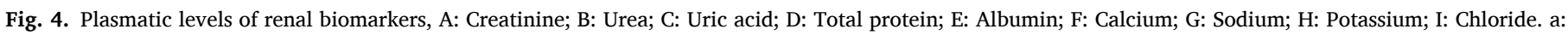

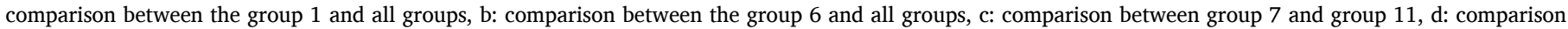
between group 8 and group 11 (the significance started at $\mathrm{p}<0.05$ ).

group $1 \mathrm{~W}$ group $2 \square$ group 3 group 4 group 5 group 6 group 7 group $8 \square$ group $9 \square$ group 10

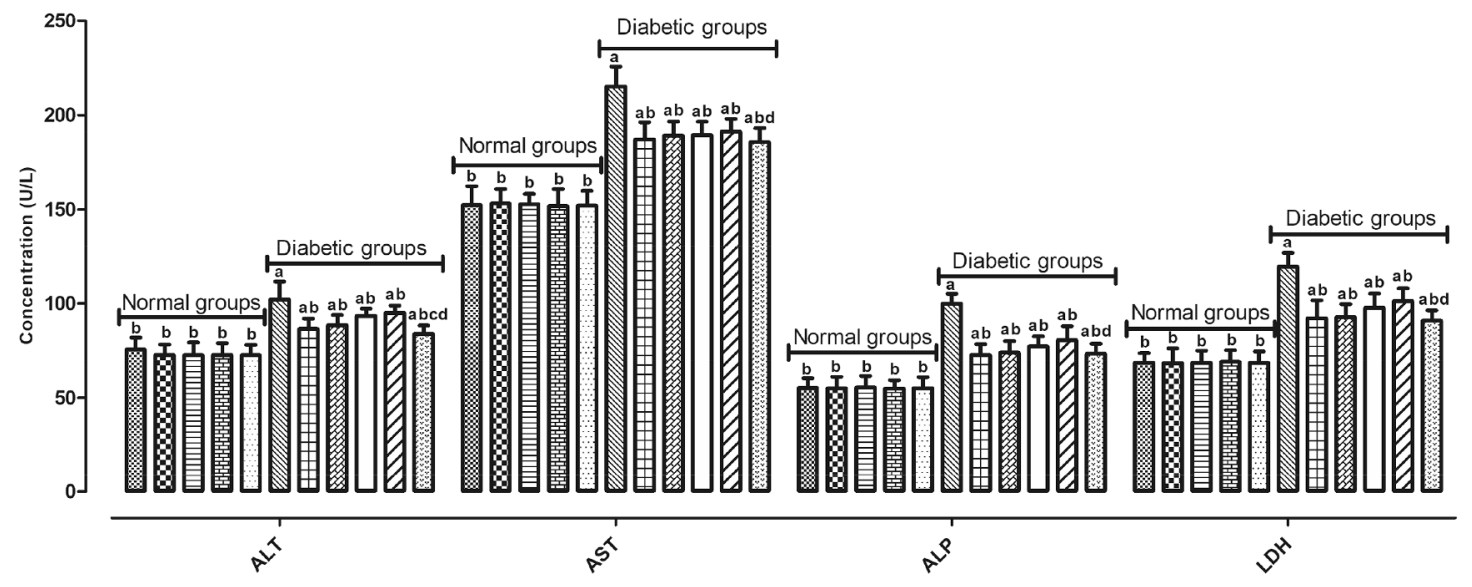

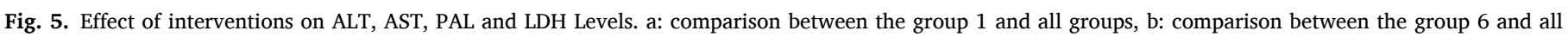
groups, c: comparison between group 7 and group 11, d: comparison between group 8 and group 11 (the significance started at p $<0.05$ ). 
Table 2

Effect of interventions on body weight.

\begin{tabular}{|c|c|c|c|c|c|c|}
\hline Experimental groups & Initial BW (g) & $\%$ Change & Final BW (g) & $\%$ Change & BW gain $(\mathrm{g})$ & \% Change \\
\hline 1 & $168.90 \pm 4.22$ & - & $212.56 \pm 4.41 b$ & - & $43.66 \pm 0.19 b$ & - \\
\hline 2 & $172.6 \pm 5.11$ & 2.19 & $200.4 \pm 3.68 b$ & -5.72 & $27.8 \pm 0.12 \mathrm{ab}$ & -36.32 \\
\hline 3 & $175.37 \pm 4.86$ & 3.83 & $280.35 \pm 6.81 \mathrm{a}$ & 31.89 & $104.98 \pm 3.14 \mathrm{ab}$ & 140.44 \\
\hline 4 & $168.45 \pm 5.13$ & -0.26 & $205.14 \pm 5.37 b$ & -3.49 & $36.69 \pm 0.79 a b$ & -15.27 \\
\hline 5 & $178.58 \pm 4.46$ & 5.69 & $263.74 \pm 4.92 \mathrm{ab}$ & 24.07 & $85.16 \pm 2.28 \mathrm{ab}$ & 95.05 \\
\hline 6 & $177.34 \pm 3.28$ & 4.99 & $298.78 \pm 5.48 \mathrm{a}$ & 40.56 & $128.44 \pm 2.20 \mathrm{a}$ & 194.18 \\
\hline 7 & $172.81 \pm 3.10$ & -2.55 & $248.62 \pm 5.37 \mathrm{ab}$ & -16.78 & $71.81 \pm 2.27 \mathrm{ab}$ & -44.58 \\
\hline 8 & $171.96 \pm 3.11$ & -3.03 & $292.76 \pm 6.96 a$ & -2.014 & $120.80 \pm 3.85 \mathrm{ab}$ & -5.94 \\
\hline 9 & $174.75 \pm 3.28$ & -1.46 & $251.93 \pm 5.23 \mathrm{ab}$ & -15.68 & $77.18 \pm 2.8 \mathrm{ab}$ & -39.90 \\
\hline 10 & $170.73 \pm 6.72$ & -3.98 & $272.41 \pm 6.58 \mathrm{ab}$ & -8.80 & $101.68 \pm 3.38 \mathrm{ab}$ & -20.83 \\
\hline 11 & $172.37 \pm 3.05$ & -2.80 & $258.34 \pm 5.19 \mathrm{ab}$ & -13.53 & $95.97 \pm 2.14 \mathrm{abcd}$ & -25.28 \\
\hline
\end{tabular}

a: comparison between the group 1 and all groups, b: comparison between the group 6 and all groups, (the significance started at $\mathrm{p}<0.05$ ).

Percentage changes (\%) were calculated by comparing the diabetic control group with normal and the diabetic treated group with diabetic control.

Table 3

Effect of interventions on absolute and relative organs weights.

\begin{tabular}{|c|c|c|c|c|c|c|}
\hline Groups & Kidney weight (g) & Liver weight (g) & Pancreas weight (g) & $\mathrm{kw} / 100 \mathrm{gBw}$ & $\mathrm{Lw} / 100 \mathrm{~g} \mathrm{Bw}$ & $\mathrm{Pw} / 100 \mathrm{~g} \mathrm{Bw}$ \\
\hline 1 & $1.92 \pm 0.07 b$ & $8.22 \pm 0.39 b$ & $1.09 \pm 0.05 b$ & $0.903 \pm 0.015 b$ & $3.867 \pm 0.088 b$ & $0.512 \pm 0.011 b$ \\
\hline 2 & $1.84 \pm 0.03 b$ & $7.41 \pm 0.46 \mathrm{ab}$ & $1.02 \pm 0.03 b$ & $0.918 \pm 0.008 b$ & $3.697 \pm 0.125 \mathrm{ab}$ & $0.508 \pm 0.008 b$ \\
\hline 3 & $2.49 \pm 0.09 b$ & $10.93 \pm 0.81 \mathrm{ab}$ & $1.47 \pm 0.05 b$ & $0.888 \pm 0.015 b$ & $3.898 \pm 0.119 \mathrm{ab}$ & $0.524 \pm 0.008 b$ \\
\hline 4 & $1.84 \pm 0.04 b$ & $7.79 \pm 0.37 b$ & $1.00 \pm 0.04 b$ & $0.896 \pm 0.007 \mathrm{~b}$ & $3.797 \pm 0.068 b$ & $0.487 \pm 0.007 b$ \\
\hline 5 & $2.37 \pm 0.07 b$ & $10.02 \pm 0.56 b$ & $1.37 \pm 0.02 b$ & $0.898 \pm 0.010 \mathrm{~b}$ & $3.799 \pm 0.080 \mathrm{~b}$ & $0.519 \pm 0.002 b$ \\
\hline 6 & $2.12 \pm 0.02 \mathrm{a}$ & $7.76 \pm 0.35 a$ & $1.19 \pm 0.09 \mathrm{a}$ & $0.709 \pm 0.003 a$ & $2.597 \pm 0.063 a$ & $0.398 \pm 0.016 a$ \\
\hline 7 & $1.98 \pm 0.09 \mathrm{ab}$ & $8.20 \pm 0.71 \mathrm{ab}$ & $1.11 \pm 0.04 \mathrm{ab}$ & $0.796 \pm 0.012 \mathrm{ab}$ & $3.298 \pm 0.102 \mathrm{ab}$ & $0.446 \pm 0.005 \mathrm{ab}$ \\
\hline 8 & $2.49 \pm 0.07 \mathrm{ab}$ & $10.54 \pm 0.58 \mathrm{ab}$ & $1.47 \pm 0.07 b$ & $0.849 \pm 0.011 \mathrm{ab}$ & $3.597 \pm 0.094 a b$ & $0.501 \pm 0.011 b$ \\
\hline 9 & $1.93 \pm 0.05 \mathrm{ab}$ & $8.31 \pm 0.71 \mathrm{ab}$ & $1.10 \pm 0.03 \mathrm{a}$ & $0.766 \pm 0.009 a b$ & $3.298 \pm 0.135 a b$ & $0.436 \pm 0.005 a$ \\
\hline 10 & $2.31 \pm 0.02 \mathrm{ab}$ & $9.26 \pm 0.58 \mathrm{ab}$ & $1.33 \pm 0.06 \mathrm{~b}$ & $0.847 \pm 0.003 \mathrm{ab}$ & $3.399 \pm 0.088 \mathrm{ab}$ & $0.488 \pm 0.009 b$ \\
\hline 11 & $2.14 \pm 0.09 \mathrm{ab}$ & $9.04 \pm 0.49 \mathrm{abcd}$ & $1.24 \pm 0.07 \mathrm{ab}$ & $0.828 \pm 0.017 a b$ & $3.499 \pm 0.094 \mathrm{abcd}$ & $0.479 \pm 0.013 \mathrm{ab}$ \\
\hline
\end{tabular}

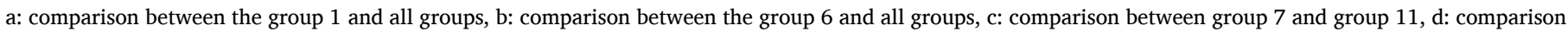
between group 8 and group $11\left({ }^{*} \mathrm{p}<0.05, * * \mathrm{p}<0.01, * * * \mathrm{p}<0.001\right)$.

\section{Discussion}

\subsection{Phytochemical composition and antioxidant activity of propolis and bee pollen extracts}

Bee products are considered as a rich source of biological active compounds. In fact, their pharmacological accomplishments are attributed to phenol and flavonoids contents (Juszczak, Gałkowska, Ostrowska, \& Socha, 2016). The data showed that propolis and bee pollen extracts exhibited high antioxidant activity and expressed a strong free radical scavenging capacity. Indeed, the amount of phenolic content in our propolis sample was $79.71 \pm 5.12 \mathrm{mg} \mathrm{GAE} / \mathrm{g}$, which was higher than that reported by (Miguel et al., 2014). For different Moroccan propolis samples, ranging from (0.74-65.7 mg GAE/g), that can be explained by botanical sources and pedoclimatic conditions.

Due to the variety in the composition of food or other biological samples, studying the antioxidant compounds is very attractive for researchers and industries due to its wide application. In this sense, the use of consistent and convenient methodologies for the rapid quantification of antioxidants is one of the important points in this type of studies.

Normally, different in vitro assays, with different mechanisms of action, are needed to confirm the antioxidant properties of natural molecules, extracts and foods. In practice, several in vitro test procedures are carried out for evaluating antioxidant activities with the samples of interest. Another aspect is that antioxidant test models vary in different respects. Therefore, it is difficult to compare fully one method to other one (Singh \& Singh, 2008).

In this sense, in our study, two independent tests were carried out to affirm the antioxidant capacity of bee pollen and propolis extracts. For example, the DPPH assay is associated with the free radical scavenging activity promoted by the compounds present in the extracts, whereas the phosphomolybdate method (where Mo (VI) is reduced to Mo (V) in the presence of antioxidant compounds) is normally associated with total antioxidant capacity.

Total antioxidant capacity $(90.17 \pm 7.38 \mathrm{mg} \mathrm{AAE} / \mathrm{g})$ go on hind with the data published by (Touzani et al., 2018), where seven Moroccan propolis samples collected from different areas in Morocco had total antioxidant activity ranging between $6.56 \pm 0.82$ and $90.87 \pm 2.91 \mathrm{mg}$ $\mathrm{AAE} / \mathrm{g}$. DPPH scavenging assay showed a powerful antiradical activity $\left(\mathrm{IC}_{50}=0.17 \pm 0.00 \mathrm{mg} / \mathrm{mL}\right.$ ), which is included in the range of Moroccan propolis, varied from $0.019 \mathrm{mg} / \mathrm{mL}$ to $1.190 \mathrm{mg} / \mathrm{mL}$ (Touzani et al., 2018). Bee pollen is another bee product; it's considered as a biological matrix very rich in natural antioxidants (Denisow \& Denisow-Pietrzyk, 2016). It was found that the total phenolic content in Polish bee pollen is $21.30 \mathrm{mg} \mathrm{GAE/g}$ (Rzepecka-Stojko, Stec, Kurzeja, Gawrońska, \& Pawłowska-Góral, 2012), in Lithuanian bee pollen is $23.3 \mathrm{mg} \mathrm{GAE} / \mathrm{g}$ (Čeksteryté et al., 2016). In the Egyptian bee pollen, the total phenolic contents were between $0.8 \pm 0.07$ and $2.3 \pm 0.014 \mathrm{mg} \mathrm{GAE} / \mathrm{g}$ (AbdElsalam, Foda, Abdel-Aziz, \& Abd, 2018). The amount of total phenolic content in our bee pollen sample is (19.68 $\pm 0.12 \mathrm{mg} \mathrm{GAE} / \mathrm{g})$, which is higher than that signaled for Egyptian bee pollen and lower than that found in Polish and Lithuanian bee pollen. Flavonoids are considered as a powerful secondary metabolite, certainly, they are responsible for several biological properties. Bee pollen's flavonoid content was previously evaluated by several studies. It was found in a range between 1.81 \pm 0.040 and $4.44 \pm 0.125 \mathrm{mg} \mathrm{QE} / \mathrm{g}$ (Mayda, Özkök, Ecem Bayram, Gerçek, \& Sorkun, 2020) in Turkish bee pollen and from $15.28 \pm 0.04$ to $31.80 \pm 0.13 \mathrm{mg}$ QE/g in Malaysian bee pollen (Harif Fadzilah, Jaapar, Jajuli, \& Wan Omar, 2017). Regarding free radical scavenging ability (DPPH), the concentration of bee pollen required to inhibit $50 \%$ of DPPH radical is $0.91 \pm 0.02 \mathrm{mg} / \mathrm{mL}$, which is lower than the published by (Mayda et al., 2020) for different bee pollen samples from Turkey, ranging between $1.29 \pm 0.03$ and $3.85 \pm 0.03 \mathrm{mg} / \mathrm{mL}$.

The qualitative and quantitative phytochemical composition of bee products is strongly variable and depend on the ecosystems and harvest year (Bankova, 2009). In fact, the soil nature, weather conditions and 
the local plant source influence their composition and consequently gives its potential health benefits and a wide spectrum of biological activity including antidiabetic, antimicrobial, antitumor, antiinflammatory, immunomodulatory and cardio protective activities (Pasupuleti, Sammugam, Ramesh, \& Gan, 2017).

\subsection{Antidiabetic effect of bee pollen and propolis extracts}

Hyperglycemia is the main cause of diabetes complications, and it is one of the factors associated with morbidity and mortality (Vichaibun, Khananurak, \& Sophonnithiprasert, 2019). Our results illustrate that 16 weeks of treatment with D-glucose induced a significant increase in blood glucose, insulinemia and HOMA-IR index, which is in agreement with the finding of (El Midaoui, Haddad, \& Couture, 2016). The measurement of insulinemia is one of the most recommended parameters used for the diagnosis of T2D (Konate et al., 2014). Chronic hyperinsulinemia induces a down regulation of insulin receptor phosphorylation and reversible reduction of receptor tyrosine kinase activity, leading to insulin resistance associated with type 2 diabetes mellitus (Catalano et al., 2014; Kanety, Moshe, Shafrir, Lunenfeld, \& Karasik, 1994). The present results showed that the co-administration of propolis or bee pollen extracts at two tested doses (100 and $200 \mathrm{mg} / \mathrm{kg} \mathrm{BW}$ ) are able to ameliorate the rise in blood glucose, HOMA-IR index and insulinemia. In the same sense, the combined treatment with propolis and pollen has remarkably reduced the level of all these parameters. Also, the diabetic animals expressed a very low value of HOMA- $\beta$ and insulin sensitivity and a significant reduction in QUICKI (marker of insulin sensitivity) concurring with the findings of (Abdel Aziz et al., 2020). However, the co-administration of propolis, bee pollen or both showed a significant increase of these parameters, with the best data observed in the group which received the combined treatment (Group 11). This may be due to the reduction of pancreatic oxidative stress generated by chronic accumulation of blood glucose. Previous data revealed that phenolic compounds have a wide diversity of pharmacological activities and strong effects on numerous chronic diseases including diabetes (Chen, Gnanaraj, Arulselvan, El-Seedi, \& Teng, 2019; Huang et al., 2019). The outcome of (Ahmed, Hassan, Abdel-Twab, \& Abdel Azeem, 2017) showed that naringin has strong anti-hyperglycemic and antihyperlipidemic effects in nicotineamide/streptozotocine induced T2D in rats. Apigenin ameliorates glucose level, vascular dysfunction and regulates lipid metabolism as well as insulin resistance in T2D rats (Ren et al., 2016). In fact, naringin and apigenin were the most predominant phenolic compounds detected in our propolis and bee pollen samples, respectively. This supports the hypothesis of their contribution in the mechanism of the anti-hyperglycemic effect and management of insulin sensitivity.

The report of (Chen et al., 2019) about phenolic acids and their mechanisms involved in the management of diabetes has shown that, ferrulic acid controls and reduces chronic blood sugar by stimulating insulin secretion and expression of GLUT4 and MAP kinase. Chlorogenic acid stimulates glucose transport by the translocation of GLUT4 and the activation of IRS-1 and PI3K signaling pathways. In addition, it inhibits hepatic Glc-6-Pasein $\mathrm{db} / \mathrm{db}$ in mice homozygous for diabetes spontaneous mutation model. Ellagic acid is another phenolic acid that has strong antidiabetic effect, in fact it is able to inhibit IL- 1 and TNF- $\alpha$ and hence, inhibits AP-1 and MAPK. Moreover, it also stimulates malondialdehyde (MDA) level in the liver and kidney tissues in diabetic mice (Konate et al., 2014). Overall, the anti-hyperglycemic effect of propolis and bee pollen used in this study could be due to the interaction between these bioactive molecules through diverse signaling pathways (Fig. 6).

\subsection{Protective effect of bee pollen and propolis extracts on liver biochemical changes}

The liver plays a crucial role in glucose and lipid homeostasis, the plasma level of ALT, AST, LDH and ALP is an essential indicator reflecting the functional status of the liver. In this study, the diabetic group expressed a remarkable increase in serum levels of ALT, AST, ALP, and LDH (Fig. 5). These results were in agreement with those reported by (Oršolić, Sirovina, Končić, Lacković, \& Gregorović, 2012). The high plasma level of ALT, AST, ALP, and LDH is an index of liver damage, indicating liver structural changes (Bakour et al., 2017), and hepatic cell necrosis, accompanied by the secretion of these enzymes into the bloodstream from the cytosol (Bakour et al., 2018). That could be attributed to the oxidative damage of ROS generated by diabetes (Kangralkar, Patil, \& Bandivadekar, 2010). However, rats receiving propolis or bee pollen simultaneously with D-glucose expressed lower levels of ALT, AST, LDH and ALP. In the same context, the combined extracts co-treatment induced a remarkable recovery of these key enzymes of the liver function. Indeed, propolis and bee pollen prompted the protective effect and prevented the complications of diabetes (Fig. 6). The protective effect of propolis and bee pollen might be due to their richness on various phytochemical compounds (Table 1). Previous study reports that resveratrol has been revealed to exert hepatoprotective action against oxidative stress-caused liver injury by activating Nrf2 signaling pathway and stimulating the production of

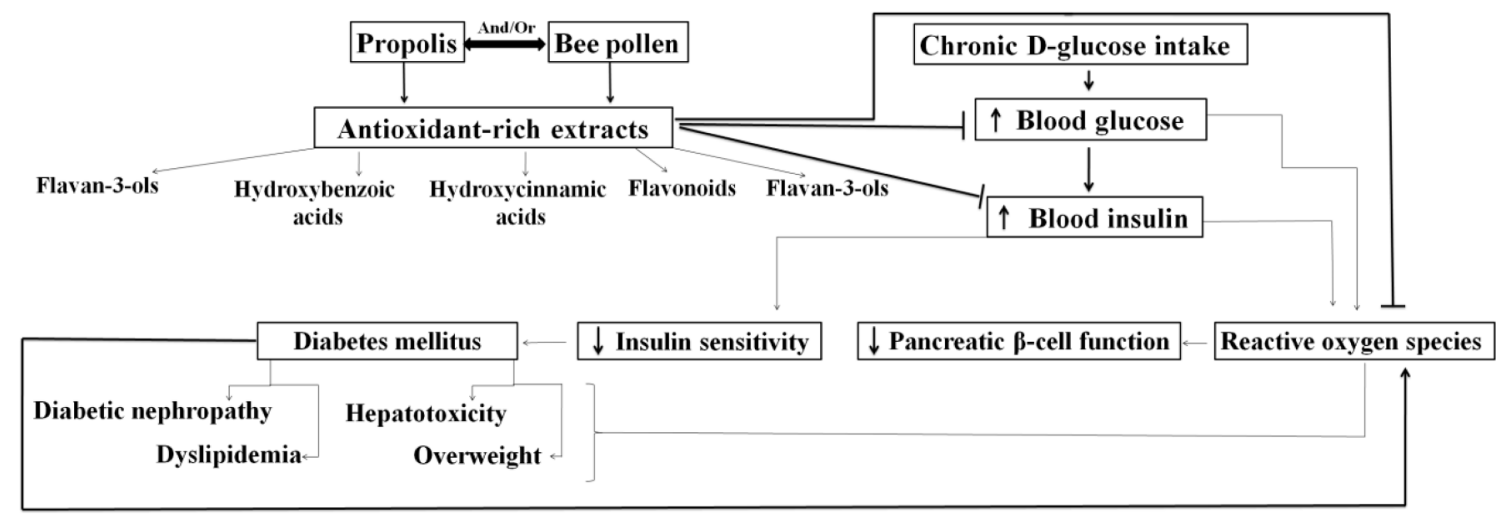

$\uparrow$ Increase

$\downarrow$ Decrease

Fig. 6. Schematic diagram showing a proposed mode of actions of bee pollen and propolis extracts in D-glucose induced type 2 diabetes, dyslipidemia and hepatorenal dysfunction. 
glutathione (GSH), catalase (CAT), superoxide dismutase (SOD), NADPH dehydrogenase quinine-1 (NQO1), heme oxygenase-1 (HO-1) and glutathione S-transferase (GST) (Jia et al., 2019).

\subsection{Protective effect of bee pollen and propolis extracts on kidney biochemical changes}

Our data indicate that free access to drinking water contained $10 \%$ of D-glucose for 16 weeks significantly increased the levels of creatinine, urea, and uric acid and decreased the total protein and albumin compared to non-diabetic control rats. These results are major sign of diabetic nephropathy, which is considered as one of the dangerous complications of diabetes (Al-Logmani \& Zari, 2011). These results are consistent with previous studies by other authors (Al-Malki \& El Rabey, 2015; Balasubramanian, Gp, \& Chatterjee, 2014). In diabetic groups the simultaneous administration of propolis or bee pollen extracts with daily ingestion of D-glucose showed a reduction in the levels of creatinine, urea, and uric acid, in contrast, a remarkable increase in albumin and total protein levels was shown. This change in plasma albumin levels induced by diabetes, may be attributed to inflammation or liver failure (Akirov, Masri-Iraqi, Atamna, \& Shimon, 2017). This is in agreement with the results of (Oršolić et al., 2012), which shows that the cotreatment with propolis at a dose of $50 \mathrm{mg} / \mathrm{kg}$ BW significantly reduces plasma levels of urea, uric acid and creatinine. Quercetin presented in bee products has been proved to prevent renal injury through the modulation of Akt/mTOR pathway as a result of its antioxidant and anti-inflammatory action (Rusul F. Hasan, Altimimi, Alaridy, \& Hadi, 2020). The concurrent treatment with propolis and bee pollen (Group 11) ameliorated these parameters and nearly restored them to their normal levels. This could be attributed to the synergistic effects between their bioactive molecules (Fig. 6).

\subsection{Protective effect of bee pollen and propolis extracts on dyslipidemia}

Type 1 diabetes (T1D) and T2D express two different forms of dyslipidemia. T1D most commonly associated with normal LDL-C and HDL$\mathrm{C}$ levels and high value of TG. However, T2D is generally characterized by low levels of HDL-C and a normal level of LDL-C and a high level of TG (Molitch, 2006). The present study showed that diabetic animals have expressed a massive elevation in plasma TC, TG, LDL-C and VLDL accompanied by a significant decrease of serum HDL-C, index of dyslipidemia. Dyslipidemia contributes to the mechanism of oxidative stress in T2D (Aouacheri, Saka, Krim, Messaadia, \& Maidi, 2015; Stahlman et al., 2013), leading to other chronic cardiovascular diseases (CVD) and atherosclerosis (Molitch, 2006). Atherosclerosis is usually associated with LDL oxidation (Matsuura, Hughes, \& Khamashta, 2008). Previous studies have shown that propolis reduces lipid peroxidation in vitro and in vivo (Inokuchi et al., 2006; Matsuura et al., 2008). This could be the mechanism involved in the prevention of cardiovascular disease CVD. In this study, the treatment of diabetic rats with propolis has restored the normal values of lipid profile, this is in agreement with the findings of (Konate et al., 2014). Also the diabetic animal's co-treated with bee pollen alone or in combination with propolis showed a significant decrease in TC, TG, LDL-C and VLDL, in parallel a significant increase in HDL-C. This confirms their preventive effect on diabetes induced dyslipidemia. Therefore, bee pollen and propolis, particularly their association have the potential to prevent and reduce CVD.

\subsection{Protective effect of bee pollen and propolis extracts on body and organs weights changes}

Body weight gain is one of the most common symptoms of T2D, especially, when the glycemic status is uncontrolled. In the present study, the chronic administration of $10 \%$ D-glucose caused a significant increase in the final body weight and body weight gain in comparison with the normal group. This is in agreement with the results of (Ross et al., 2011), illustrating the association of T2D and obesity. Opposite toT1D, which is manifested by the body weight loss (Mohamed, Ahmed, Hozayen, \& Ahmed, 2018). This may be explained by the anabolic effect of insulin and it ability to stimulate cell growth and promote storage of fatty acids in adipose and muscle tissue (Brown, Guess, Dornhorst, Taheri, \& Frost, 2017). Hence, the co-administration of propolis at a high and a low dose and the co-administration of bee pollen at same doses have significantly reduced the body weight and the body weight gain compared to the diabetic group. The decrease of body weight following the co-treatment with propolis is more significant than bee pollen co-treatment. The body weight decrease of diabetic rats cotreated with propolis extracts is probably due to its repressive effect on PPAR $\gamma$ protein expression, which attenuated fat accumulation in adipocytes (Rayalam et al., 2007). In the same context, it was found that propolis administration inhibits cholesterol synthesis by decreasing hepatic HMG-CoA reductase protein (Ichi et al., 2009).

Also the Table 3 showed that the treatment with propolis or bee pollen does not affect the organs relative weight. The data illustrates that the treatment with D-glucose for 4 months caused a significant decrease of organs' relative weight (liver, kidney and pancreas) in comparison with the control group, this goes in hand with the findings of (Bai, Zang, Ma, \& Xu, 2016). However, the co-treatment with propolis alone, pollen alone or both had induced a marginal increase in kidney, liver and pancreas's relative weight. This is consistent with results of (Mohamed et al., 2018). The liver weight loss may occur as a result of the breakdown of glycogen, lipids and proteins caused by lack of insulin in liver cells (Qaid \& Abdelrahman, 2016). In general, the decrease of organs' relative weights can be attributed to the destruction of its cells by the excess of free radicals generated through diabetes, which is illustrated by the biochemical parameters.

\section{Conclusion}

Overall, the results of this study showed for the first time that coadministration of propolis and bee pollen extracts, especially their combination, are able to attenuate the T2D caused by a high-glucose intake. The role of these natural ingredients involves prevention of hyperglycemia, insulinemia, HOMA-IR index, HOMA- $\beta$, Insulin sensitivity, pancreatic $\beta$-cell function and lipid prolife. Furthermore, these natural products ameliorate hepatotoxicity and nephrotoxicity as diabetic complications.

\section{Funding}

This work was supported by a grant from Laboratory of Natural Substances, Pharmacology, Environment, Modeling, Health and Quality of Life (SNAMOPEQ).

This research was funded by the Portuguese Foundation for Science and Technology (FCT) under the scope of the strategic funding of UIDB/ 04469/2020 unit and Bio Tec Norteoperation (NORTE-01-0145-FEDER000004) funded by the European Regional Development Fund (FEDER) under the scope of Norte2020-Programa Operacional Regional do Norte. Zlatina Genisheva is supported by the project OH2O (POCI-01-0145FEDER-029145) funded by FCT and FEDER under the scope of Programa Operacional de Competividade e Internacionalizaçao (POCI)-COMPETE 2020 and PORTUGAL2020. Pedro Santos is recipient of a fellowship supported by a doctoral advanced training (call NORTE-69-2015-15), funded by the European Social Fund under the scope of Norte2020 (NORTE-08-5369-FSE-000036).

\section{Author contributions}

Hassan Laaroussi: In vivo designed and performed experimental studies and manuscript preparation. Meryem Bakour: Designed the experiments, treatment of data and manuscript review. Driss Ousaaid: In vitro performed experimental analysis. Abderrazak Aboulghazi: Performed biochemical analysis. Pedro Ferreira-Santos: Identification and quantification of bioactive compounds and development of 
individual phenolic composition part. Zlatina Genisheva: Running UHPLC-DAD and manuscript revision. José Antonio Teixeira: Proof reading and manuscript review. Badiaa Lyoussi: Methodology of work, data analysis, manuscript review and submission procedure.

\section{Declaration of Competing Interest}

The authors declare that they have no known competing financial interests or personal relationships that could have appeared to influence the work reported in this paper.

\section{Acknowledgements}

The authors wish to thank Mr. M. Hamdan Rodriguez for proofreading.

\section{References}

Abdel Aziz, S. M., Ahmed, O. M., Abd EL-Twab, S. M., Al-Muzafar, H. M., Amin, K. A., \& Abdel-Gabbar, M. (2020). Antihyperglycemic effects and mode of actions of Musa paradisiaca leaf and fruit peel hydroethanolic extracts in nicotinamide/ streptozotocin-induced diabetic rats. Evidence-Based Complementary and Alternative Medicine, 2020, 1-15.

AbdElsalam, E., Foda, H. S., Abdel-Aziz, M. S., \& Abd, F. K. (2018). Antioxidant and antimicrobial activities of Egyptian bee pollen. Sciences, 8(04), 1248-1255.

Ahmed, O. M., Hassan, M. A., Abdel-Twab, S. M., \& Abdel Azeem, M. N. (2017). Navel orange peel hydroethanolic extract, naringin and naringenin have anti-diabetic potentials in type 2 diabetic rats. Biomedicine \& Pharmacotherapy, 94, 197-205.

Akirov, A., Masri-Iraqi, H., Atamna, A., \& Shimon, I. (2017). Low albumin levels are associated with mortality risk in hospitalized patients. The American Journal of Medicine, 130(12), 1465.e11-1465.e19.

Al-Hariri, M. T. (2011). Propolis and its direct and indirect hypoglycemic effect. Journal of Family \& Community Medicine, 18(3), 152-154. https://doi.org/10.4103/22308229.90015 .

Al-Logmani, A., \& Zari, T. (2011). Long-term effects of Nigella sativa L. oil on some physiological parameters in normal and streptozotocin-induced diabetic rats. JDM, 01(03), 46-53.

Al-Malki, A. L. (2013). Oat attenuation of hyperglycemia-induced retinal oxidative stress and NF-B activation in streptozotocin-induced diabetic rats. Evidence-Based Complementary and Alternative Medicine, 2013, 1-8.

Al-Malki, A. L., \& El Rabey, H. A. (2015). The antidiabetic effect of low doses of Moringa oleifera Lam. seeds on streptozotocin induced diabetes and diabetic nephropathy in male rats. BioMed Research International, 2015, 1-13.

American Diabetes Association. (2013). Diagnosis and classification of diabetes mellitus. Diabetes Care, 36 Suppl 1(Suppl 1), S67-S74. PubMed. https://doi.org/10.2337/ dc13-S067.

Aouacheri, O., Saka, S., Krim, M., Messaadia, A., \& Maidi, I. (2015). The investigation of the oxidative stress-related parameters in type 2 diabetes mellitus. Canadian Journal of Diabetes, 39(1), 44-49. https://doi.org/10.1016/j.jcjd.2014.03.002.

Bai, Y.u., Zang, X., Ma, J., \& Xu, G. (2016). Anti-diabetic effect of Portulaca oleracea L. polysaccharideandits mechanism in diabetic rats. IJMS, 17(8), 1201. https://doi. org/10.3390/ijms17081201.

Bakour, M., Al-Waili, N. S., El Menyiy, N., Imtara, H., Figuira, A. C., Al-Waili, T., \& Lyoussi, B. (2017). Antioxidant activity and protective effect of bee bread (honey and pollen) in aluminum-induced anemia, elevation of inflammatory makers and hepato-renal toxicity. Journal of Food Science and Technology, 54(13), 4205-4212.

Bakour, M., Soulo, N., Hammas, N., Fatemi, H., Aboulghazi, A., Taroq, A., ... Lyoussi, B. (2018). The antioxidant content and protective effect of argan oil and Syzygium aromaticum essential oil in hydrogen peroxide-induced biochemical and histological changes. IJMS, 19(2), 610. https://doi.org/10.3390/ijms19020610.

Balasubramanian, T., Gp, S., \& Chatterjee, T. (2014). Therapeutic effect of stereospermum suavelolens on diabetic nephropathy. Clinical \& Experimental Pharmacology.

Bankova, V. (2009). Chemical diversity of propolis makes it a valuable source of new biologically active compounds. Journal of Apiproduct and Apimedical Science, 1(2), 23-28.

Brown, A., Guess, N., Dornhorst, A., Taheri, S., \& Frost, G. (2017). Insulin-associated weight gain in obese type 2 diabetes mellitus patients: What can be done? Diabetes, Obesity \& Metabolism, 19(12), 1655-1668.

Burdock, G. A. (1998). Review of the biological properties and toxicity of bee propolis (propolis). Food and Chemical Toxicology, 36(4), 347-363.

Catalano, K. J., Maddux, B. A., Szary, J., Youngren, J. F., Goldfine, I. D., Schaufele, F., \& Kanzaki, M. (2014). Insulin resistance induced by hyperinsulinemia coincides with a persistent alteration at the insulin receptor tyrosine kinase domain. PLOS ONE, 9(9), e108693. https://doi.org/10.1371/journal.pone.0108693.

Čeksteryté, V., Kurtinaitienè, B., Venskutonis, P. R., Pukalskas, A., Kazernavičiūtè, R., \& Balžekas, J. (2016). Evaluation of antioxidant activity and flavonoid composition in differently preserved bee productsEvaluation of antioxidant activity and flavonoid composition in differently preserved bee products. Czechoslovak Journal of Food Sciences, 34(No. 2), 133-142. https://doi.org/10.17221/312/2015-CJFS.
Chen, L., Gnanaraj, C., Arulselvan, P., El-Seedi, H., \& Teng, H. (2019). A review on advanced microencapsulation technology to enhance bioavailability of phenolic compounds: Based on its activity in the treatment of Type 2 Diabetes. Trends in Food Science \& Technology, 85, 149-162. https://doi.org/10.1016/j.tifs.2018.11.026.

Denisow, B., \& Denisow-Pietrzyk, M. (2016). Biological and therapeutic properties of bee pollen: A review: Bee pollen and medicine. Journal of the Science of Food and Agriculture, 96(13), 4303-4309.

Ebrahimi, R., Sepand, M. R., Seyednejad, S. A., Omidi, A., Akbariani, M., Gholami, M., \& Sabzevari, O. (2019). Ellagic acid reduces methotrexate-induced apoptosis and mitochondrial dysfunction via up-regulating Nrf2 expression and inhibiting the IкB $\alpha /$ NFKB in rats. Daru: Journal of Faculty of Pharmacy, Tehran University of Medical Sciences, 27(2), 721-733. https://doi.org/10.1007/s40199-019-00309-9.

El Menyiy, N., Al Waili, N., Bakour, M., Al-Waili, H., \& Lyoussi, B. (2016). Protective effect of propolis in proteinuria, crystaluria, nephrotoxicity and hepatotoxicity induced by ethylene glycol ingestion. Archives of Medical Research, 47(7), 526-534. https://doi.org/10.1016/j.arcmed.2016.12.010.

El Menyiy, N., Al-Wali, N., El Ghouizi, A., El-Guendouz, S., Salom, K., \& Lyoussi, B. (2019). Potential therapeutic effect of Moroccan propolis in hyperglycemia, dyslipidemia, and hepatorenal dysfunction in diabetic rats. Iranian Journal of Basic Medical Sciences, 22(11), 1331-1339. https://doi.org/10.22038/ ijbms.2019.33549.8004.

El Midaoui, A., Haddad, Y., \& Couture, R. (2016). Beneficial effects of argan oil on blood pressure, insulin resistance, and oxidative stress in rat. Nutrition, 32(10), 1132-1137. https://doi.org/10.1016/j.nut.2016.02.021.

El-Guendouz, S., Aazza, S., Lyoussi, B., Antunes, M. D., Faleiro, M. L., \& Miguel, M. G. (2016). Anti-acetylcholinesterase, antidiabetic, anti-inflammatory, antityrosinase and antixanthine oxidase activities of Moroccan propolis. International Journal of Food Science \& Technology, 51(8), 1762-1773. https://doi.org/10.1111/ijfs.13133.

Harif Fadzilah, N., Jaapar, M. F., Jajuli, R., \& Wan Omar, W. A. (2017). Total phenolic content, total flavonoid and antioxidant activity of ethanolic bee pollen extracts from three species of Malaysian stingless bee. Journal of Apicultural Research, 56(2), 130-135. https://doi.org/10.1080/00218839.2017.1287996.

Fakhruddin, S., Alanazi, W., \& Jackson, K. E. (2017). Diabetes-induced reactive oxygen species: Mechanism of their generation and role in renal injury. Journal of Diabetes Research, 2017, 1-30. https://doi.org/10.1155/2017/8379327.

El Ghouizi, A., El Menyiy, N., Falcão, S. I., Vilas-Boas, M., \& Lyoussi, B. (2020). Chemical composition, antioxidant activity, and diuretic effect of Moroccan fresh bee pollen in rats. Veterinary World, 13(7), 1251-1261. https://doi.org/10.14202/ vetworld.2020.1251-1261.

Hoşnuter, M., Gürel, A., Babucçu, O., Armutcu, F., Kargi, E., \& Işikdemir, A. (2004). The effect of CAPE on lipid peroxidation and nitric oxide levels in the plasma of rats following thermal injury. Burns, 30(2), 121-125. https://doi.org/10.1016/j. burns.2003.09.022.

Huang, P.-K., Lin, S.-R., Chang, C.-H., Tsai, M.-J., Lee, D.-N., \& Weng, C.-F. (2019). Natural phenolic compounds potentiate hypoglycemia via inhibition of Dipeptidyl peptidase IV. Scientific Reports, 9(1). https://doi.org/10.1038/s41598-019-52088-7.

Ichi, I., Hori, H., Takashima, Y., Adachi, N., Kataoka, R., Okihara, K., Hashimoto, K., \& Kojo, S. (2009). The beneficial effect of propolis on fat accumulation and lipid metabolism in rats fed a high-fat diet. Journal of Food Science, 74(5), H127-H131. https://doi.org/10.1111/j.1750-3841.2009.01147.x.

Inokuchi, Y., Shimazawa, M., Nakajima, Y., Suemori, S., Mishima, S., \& Hara, H. (2006). Brazilian green propolis protects against retinal damage in vitro and in vivo. EvidenceBased Complementary and Alternative Medicine, 3(1), 71-77. https://doi.org/ 10.1093/ecam/nek005.

Jia, R., Li, Y., Cao, L., Du, J., Zheng, T., Qian, H., ... Yin, G. (2019). Antioxidative, antiinflammatory and hepatoprotective effects of resveratrol on oxidative stress-induced liver damage in tilapia (Oreochromis niloticus). Comparative Biochemistry and Physiology Part C: Toxicology \& Pharmacology, 215, 56-66. https://doi.org/10.1016/ j.cbpc.2018.10.002.

Juszczak, L., Gałkowska, D., Ostrowska, M., \& Socha, R. (2016). Antioxidant activity of honey supplemented with bee products. Natural Product Research, 30(12), 1436-1439. https://doi.org/10.1080/14786419.2015.1057582.

Kanety, H., Moshe, S., Shafrir, E., Lunenfeld, B., \& Karasik, A. (1994). Hyperinsulinemia induces a reversible impairment in insulin receptor function leading to diabetes in the sand rat model of NIDDM. Proceedings of the National Academy of Sciences of the United States of America, 91, 1853-1857. https://doi.org/10.1073/pnas.91.5.1853.

Kangralkar, V., Patil, S. D., \& Bandivadekar, R. (2010). Oxidative stress and diabetes: A review. Int J Pharm Appl, 1(1), 38-45.

Karim, N., Rahman, M. A., Changlek, S., \& Tangpong, J. (2020). Short-time administration of xanthone from Garcinia mangostana fruit pericarp attenuates the hepatotoxicity and renotoxicity of type II diabetes mice. Journal of the American College of Nutrition, 39(6), 501-510. https://doi.org/10.1080/ 07315724.2019.1696251.

Katsuda, Y., Ohta, T., Miyajima, K., Kemmochi, Y., Sasase, T., Tong, B., Shinohara, M., \& Yamada, T. (2014). Diabetic complications in obese type 2 diabetic rat models. Experimental Animals, 63(2), 121-132. https://doi.org/10.1538/expanim.63.121.

Katz, A., Nambi, S. S., Mather, K., Baron, A. D., Follmann, D. A., Sullivan, G., \& Quon, M. J. (2000). Quantitative insulin sensitivity check index: A simple, accurate method for assessing insulin sensitivity in humans. The Journal of Clinical Endocrinology and Metabolism, 85(7), 2402-2410. https://doi.org/10.1210/ jcem.85.7.6661.

Konaté, K., Yomalan, K., Sytar, O., Zerbo, P., Brestic, M., Patrick, V. D., ... Barro, N. (2014). Free radicals scavenging capacity, antidiabetic and antihypertensive activities of flavonoid-rich fractions from leaves of Trichilia emetica and Opilia amentacea in an animal model of type 2 diabetes mellitus. Evidence-Based 
Complementary and Alternative Medicine, 2014, 1-13. https://doi.org/10.1155/2014/ 867075.

Kong, K. W., Mat-Junit, S., Aminudin, N., Ismail, A., \& Abdul-Aziz, A. (2012). Antioxidant activities and polyphenolics from the shoots of Barringtonia racemosa (L.) Spreng in a polar to apolar medium system. Food Chemistry, 134(1), 324-332. https://doi.org/10.1016/j.foodchem.2012.02.150.

Leja, M., Mareczek, A., Wyżgolik, G., Klepacz-Baniak, J., \& Czekońska, K. (2007). Antioxidative properties of bee pollen in selected plant species. Food Chemistry, 100 (1), 237-240. https://doi.org/10.1016/j.foodchem.2005.09.047.

Matsuura, E., Hughes, G. R. V., \& Khamashta, M. A. (2008). Oxidation of LDL and its clinical implication. Autoimmunity Reviews, 7(7), 558-566. https://doi.org/10.1016/ j.autrev.2008.04.018.

Matthews, D. R., Hosker, J. P., Rudenski, A. S., Naylor, B. A., Treacher, D. F., \& Turner, R. C. (1985). Homeostasis model assessment: Insulin resistance and beta-cell function from fasting plasma glucose and insulin concentrations in man. Diabetologia 28(7), 412-419. https://doi.org/10.1007/bf00280883.

Mayda, N., Özkök, A., Ecem Bayram, N., Gerçek, Y. C., \& Sorkun, K. (2020). Bee bread and bee pollen of different plant sources: Determination of phenolic content, antioxidant activity, fatty acid and element profiles. Food Measure, 14(4), 1795-1809. https://doi.org/10.1007/s11694-020-00427-y.

Miguel, M.d. G., Doughmi, O., Aazza, S., Antunes, D., \& Lyoussi, B. (2014). Antioxidant, anti-inflammatory and acetylcholinesterase inhibitory activities of propolis from different regions of Morocco. Food Science and Biotechnology, 23(1), 313-322. https://doi.org/10.1007/s10068-014-0044-1.

Mohamed, N. A., Ahmed, O. M., Hozayen, W. G., \& Ahmed, M. A. (2018). Ameliorative effects of bee pollen and date palm pollen on the glycemic state and male sexual dysfunctions in streptozotocin-Induced diabetic wistar rats. Biomedicine \& Pharmacotherapy = Biomedecine \& Pharmacotherapie, 97, 9-18. https://doi.org/ 10.1016/j.biopha.2017.10.117.

Molitch, M. E. (2006). Management of dyslipidemias in patients with diabetes and chronic kidney disease. CJASN, 1(5), 1090-1099. https://doi.org/10.2215/ CJN.00780306.

Ogar, I., Egbung, G. E., Nna, V. U., Atangwho, I. J., \& Itam, E. H. (2019). Hyptis verticillata attenuates dyslipidaemia, oxidative stress and hepato-renal damage in streptozotocin-induced diabetic rats. Life Sciences, 219, 283-293. https://doi.org/ 10.1016/j.lfs.2019.01.027.

Ogurtsova, K., da Rocha Fernandes, J. D., Huang, Y., Linnenkamp, U., Guariguata, L., Cho, N. H., ... Makaroff, L. E. (2017). IDF diabetes atlas: Global estimates for the prevalence of diabetes for 2015 and 2040. Diabetes Research and Clinical Practice, 128, 40-50. https://doi.org/10.1016/j.diabres.2017.03.024.

Oršolić, N., Sirovina, D., Končić, M. Z., Lacković, G., \& Gregorović, G. (2012). Effect of Croatian propolis on diabetic nephropathy and liver toxicity in mice. BMC Complementary and Alternative Medicine, 12(1). https://doi.org/10.1186/1472-688212-117.

Ousaaid, D., Laaroussi, H., Bakour, M., ElGhouizi, A., Aboulghazi, A., Lyoussi, B., \& ElArabi, I. (2020). Beneficial effects of apple vinegar on hyperglycemia and hyperlipidemia in hypercaloric-fed rats. Journal of Diabetes Research, 2020, 1-7. https://doi.org/10.1155/2020/9284987.

Park, Y. K., \& Ikegaki, M. (1998). Preparation of water and ethanolic extracts of propolis and evaluation of the preparations. Bioscience, Biotechnology, and Biochemistry, 62 (11), 2230-2232. https://doi.org/10.1271/bbb.62.2230.

Pasupuleti, V. R., Sammugam, L., Ramesh, N., \& Gan, S. H. (2017). Honey, propolis, and royal jelly: A comprehensive review of their biological actions and health benefits. Oxidative Medicine and Cellular Longevity, 2017, 1-21. https://doi.org/10.1155/ 2017/1259510.

Pietta, P. G., Gardana, C., \& Pietta, A. M. (2002). Analytical methods for quality control of propolis. Fitoterapia, 73(Suppl 1), S7-S20. https://doi.org/10.1016/s0367-326x (02)00186-7.

Poitout, V., Amyot, J., Semache, M., Zarrouki, B., Hagman, D., \& Fontés, G. (2010). Glucolipotoxicity of the pancreatic beta cell. Biochimica et Biophysica Acta (BBA) -
Molecular and Cell Biology of Lipids, 1801(3), 289-298. https://doi.org/10.1016/j. bbalip.2009.08.006.

Prieto, P., Pineda, M., \& Aguilar, M. (1999). Spectrophotometric quantitation of antioxidant capacity through the formation of a phosphomolybdenum complex: Specific application to the determination of vitamin E. Analytical Biochemistry, 269 (2), 337-341. https://doi.org/10.1006/abio.1999.4019.

Qaid, M. M., \& Abdelrahman, M. M. (2016). Role of insulin and other related hormones in energy metabolism-A review. Cogent Food \& Agriculture, 2(1). https://doi.org/ 10.1080/23311932.2016.1267691.

Rayalam, S., Della-Fera, M. A., Yang, J.-Y., Park, H. J., Ambati, S., \& Baile, C. A. (2007). Resveratrol potentiates genistein's antiadipogenic and proapoptotic effects in 3T3-L1 adipocytes. The Journal of Nutrition, 137(12), 2668-2673. https://doi.org/10.1093/ jn/137.12.2668.

Ren, B., Qin, W., Wu, F., Wang, S., Pan, C., Wang, L., Zeng, B., Ma, S., \& Liang, J. (2016). Apigenin and naringenin regulate glucose and lipid metabolism, and ameliorate vascular dysfunction in type 2 diabetic rats. European Journal of Pharmacology, 773, 13-23. https://doi.org/10.1016/j.ejphar.2016.01.002.

Ross, S. A., Dzida, G., Vora, J., Khunti, K., Kaiser, M., \& Ligthelm, R. J. (2011). Impact of weight gain on outcomes in type 2 diabetes. Current Medical Research and Opinion, 27 (7), 1431-1438. https://doi.org/10.1185/03007995.2011.585396.

Hasan, R. F., Altimimi, M. L., Alaridy, H. M., \& Hadi, N. R. (2020). Nephroprotective potential effect of quercttin in renal ischemia reperfusion injury in rat model (role of Akt/m TOR pathway). SRP, 11(1), 315. https://doi.org/10.5530/srp.2020.1.41.

Rzepecka-Stojko, A., Stec, M., Kurzeja, E., Gawrońska, E., \& Pawłowska-Góral, K. (2012). The effect of storage of bee pollen extracts on polyphenol content. Polish Journal of Environmental Studies, 21, 1007-1011.

Rzepecka-Stojko, A., Stojko, J., Kurek-Górecka, A., Górecki, M., Kabała-Dzik, A., Kubina, R., ... Buszman, E. (2015). Polyphenols from bee pollen: Structure, absorption, metabolism and biological activity. Molecules, 20(12), 21732-21749. https://doi.org/10.3390/molecules201219800.

Ferreira-Santos, P., Genisheva, Z., Pereira, R. N., Teixeira, J. A., \& Rocha, C. M. R. (2019). Moderate electric fields as a potential tool for sustainable recovery of phenolic compounds from Pinus pinaster bark. ACS Sustainable Chemistry \& Engineering, 7(9), 8816-8826. https://doi.org/10.1021/acssuschemeng.9b00780.

Sforcin, J. M., \& Bankova, V. (2011). Propolis: Is there a potential for the development of new drugs? Journal of Ethnopharmacology, 133(2), 253-260. https://doi.org/ 10.1016/j.jep.2010.10.032.

Sina, M., Graffy, J., \& Simmons, D. (2018). Associations between barriers to self-care and diabetes complications among patients with type 2 diabetes. Diabetes Research and Clinical Practice, 141, 126-131. https://doi.org/10.1016/j.diabres.2018.04.031.

Singh, S., \& Singh, R. P. (2008). In vitro methods of assay of antioxidants: An overview. Food Reviews International, 24(4), 392-415. https://doi.org/10.1080/ 87559120802304269.

Ståhlman, M., Fagerberg, B., Adiels, M., Ekroos, K., Chapman, J. M., Kontush, A., \& Borén, J. (2013). Dyslipidemia, but not hyperglycemia and insulin resistance, is associated with marked alterations in the HDL lipidome in type 2 diabetic subjects in the DIWA cohort: Impact on small HDL particles. Biochimica et Biophysica Acta (BBA) - Molecular and Cell Biology of Lipids, 1831(11), 1609-1617. https://doi.org/ 10.1016/j.bbalip.2013.07.009.

Touzani, S., Al-Waili, N., N., el Menyiy, N., Bratko, F., Pereyra, A., El, I., Al-Waili, W., Badiaa, L. (2018). Chemical analysis and antioxidant content of various propolis samples collected from different regions and their impact on antimicrobial activities. Asian Pacific Journal of Tropical Medicine, 11. https://doi.org/10.4103/19957645.237188.

Vichaibun, Virun, Khananurak, Kamonwan, \& Sophonnithiprasert, Thanet (2019). Comparative analysis of plasma total antioxidant capacity in patients with hyperglycemia and hyperglycemia plus dyslipidemia. Diabetes \& Metabolic Syndrome: Clinical Research \& Reviews, 13(1), 90-94. https://doi.org/10.1016/j. dsx.2018.08.029. 